Article

\title{
An Update of the Occurrence of Organic Contaminants of Emerging Concern in the Canary Islands (Spain)
}

\author{
Maria Esther Torres-Padrón *, Sarah Montesdeoca-Esponda, Sergio Santana-Viera,

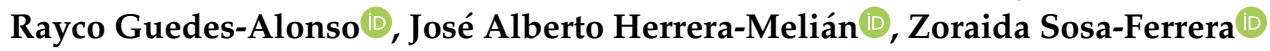 \\ and José Juan Santana-Rodríguez $\mathbb{D}$
}

Instituto Universitario de Estudios Ambientales y Recursos Naturales (i-UNAT), Universidad de Las Palmas de Gran Canaria, 35017 Las Palmas de Gran Canaria, Spain; sarah.montesdeoca@ulpgc.es (S.M.-E.); sergio.viera@ulpgc.es (S.S.-V.); rayco.guedes@ulpgc.es (R.G.-A.); josealberto.herrera@ulpgc.es (J.A.H.-M.); zoraida.sosa@ulpgc.es (Z.S.-F.); josejuan.santana@ulpgc.es (J.J.S.-R.)

* Correspondence: miriam.torres@ulpgc.es

Received: 27 July 2020; Accepted: 9 September 2020; Published: 12 September 2020

check for updates

\begin{abstract}
Nowadays, activities associated with industries, cities, and leisure generate a number of different wastes, including many chemical pollutants that enter the environment and negatively affect the wildlife. Some of them are emerging organic contaminants (EOCs), which include UV filters and stabilizers, antineoplastic agents, and natural and synthetic steroid hormones, among others. It is well demonstrated that the presence of this kind of contaminants may produce adverse effects in aquatic environments and also in marine organisms. Even though the Canary Islands (Spain) are one of the most biodiverse parts of the temperature regions of the world, little is known about the presence of these substances in the environment and organisms in the archipelago. For that purpose, the objective of this work was to evaluate the presence of some UV filters, cytostatic compounds, and hormones in water (wastewater and seawater), sediments, and marine organisms. Moreover, we evaluated conventional and natural wastewater treatment plants (WWTPs) to study the removal efficiencies of these target compounds. UV filters and stabilizers were found in all the analysed samples and were the only target family found in seawater (with UV-329 appearing at all the locations at concentrations between 67.5 and $859 \mathrm{ng} \mathrm{L}^{-1}$ ). Some cytostatic compounds were detected in hospital wastewater at concentrations between 375.8 and $1851 \mathrm{ng} \mathrm{L}^{-1}$, but not in the analysis of sludge or fish samples. Hormones were detected in wastewater, sludge, and fish samples, and their removal in the natural treatment system (over $76 \%$ for all the hormones) allowed to prove it as an efficient technology for the elimination of these EOCs from urban wastewaters in small communities.
\end{abstract}

Keywords: emerging contaminants; monitoring; extraction; wastewater treatments; Canary Islands

\section{Introduction}

The increases in the world's population, industrial activities, and the use of chemical products in domestic life and tourism, among others, are generating an important volume and complexity of waste, with the mixing of different chemicals that enter the environment via different pathways (runoff, atmosphere, and/or direct disposal). Different studies have shown that wastewater is the main source of pollutants. Effluents from wastewater treatment plants (WWTPs) are discharged into rivers, groundwater, or the sea, and the pollutants can enter trophic chains and bioaccumulate in living organisms [1,2]. In fact, more than 100,000 chemicals are used commercially. Pharmaceuticals and personal care products (PPCPs), surfactants, plasticizers, hormones, flame retardants, and industrial additives, among others, belong to the group of the so-called emerging organic contaminants (EOCs). 
Compounds such as UV filters and stabilizers, antineoplastic agents, natural and steroid hormones, metabolites, and intermediate degradation products of parent compounds are also included [3]. Their use has been increasing in recent years, although they may have been present in the environment for a long time [4].

Many EOCs are persistent, and different authors have demonstrated that they are mutagenic, carcinogenic, and can alter the endocrine system. For example, benzotriazole UV stabilizers (BUVSs) increase hatching times and affect mitochondrial function [5,6]. Therefore, the European Union legislated to limit the concentration of EOCs in effluents with the goals of protecting the marine environment and promoting the rehabilitation of affected areas by the year 2020 [7]. Moreover, special attention should be paid to coastal areas because they host a large part of the world's population and sustain approximately $99 \%$ of the world's fishing activity [8]. The EOCs concentrations in the marine environment are generally very low; so, they do not cause immediate effects in organisms, but prolonged exposure may produce chronic effects or more subtle effects such as metabolic or reproductive changes in different species [9].

Since wastewater is the main source of emerging pollutants to the marine ecosystem, it is essential to monitor the types of compounds that are being discharged and their concentrations. Comparison between influents and effluents in the WWTPs is also important to evaluate the removal efficiency. Additionally, sampling in WWTP outfalls can indicate whether the purified effluents are harmful for the aquatic environment despite the great dilution that occurs when they are discharged into the sea.

Recent studies in different countries have shown that only $10 \%$ of bioactive chemical compounds can be eliminated in WWTPs, with the presence of these substances being detected in wastewater [10], groundwater [11], surface water [12], agricultural land [13], sewage sludge [14], sediments [15], and organisms [15-17].

Therefore, determination and monitoring of EOCs is necessary to ascertain their presence in the environment and to develop effective processes of elimination in WWTPs. However, the presence of EOCs in wastewaters due to domestic activities and their consequent discharge into the aquatic environment occurs not only in heavily populated areas but also in small communities or isolated areas, where the effects could be even worse if untreated wastewater is discharged into the environment. In this case, the best alternative to the conventional wastewater treatment processes is the application of the sustainable, low-cost, natural treatment systems [18].

In the Canary Islands, due to land fragmentation and difficult orography, it is very common to find small and isolated inhabited areas where the installation and maintenance of sewage systems is difficult and expensive. Therefore, the use of natural treatment systems is quite often the most adequate alternative.

Natural wastewater treatment systems are more sustainable than conventional ones because they rely on the purification capacity of microorganisms, soils, and plants with little or nil energy consumption [19]. Molinos-Senante et al. have stated that waste-stabilization ponds and constructed wetlands (CWs) are suitable and a great option for small communities in comparison to conventional systems [20]. Water-stabilization ponds used for water treatment are designed to remove organic matter, pollutants, and pathogens via physical and biological processes [21]. These systems are easy to design and build, require little maintenance, and for these reasons have been used in developing countries [22]. CWs are substrate and plant filters in which wastewater is treated via physical processes, such as sorption, and biological processes, such as biodegradation or plant uptake. CWs can be divided into horizontal- or vertical-flow CWs depending on the flow of the water in the system. Additionally, horizontal-flow constructed wetlands (HF CWs) can be divided into surface-flow and subsurface-flow CWs [23].

In Spain, in general, and in the Canary Islands in particular, very little is known about the presence of EOCs in the coast and their effects on the marine environment. The Canary Islands are a biodiversity hotspot archipelago located in the Atlantic Ocean to the northwest of Africa. They are also a chosen destination for national and international tourists because of their beaches and weather, 
receiving more than 15 million tourists in 2017 according to the Canary Institute of Statistics (ISTAC, http://www.gobiernodecanarias.org/istac/). The island of Gran Canaria concentrates an important part of the population, more than 850,000 people, and many of the beaches of the island support a significant touristic load (more than 350,000 per month according to ISTAC data). However, no studies have attempted to determine the environmental conditions in coastal areas due to the occurrence of EOCs in this region. Monitoring these types of compounds can provide solutions to the environmental problems generated by their presence in the effluents of WWTPs. To the best of our knowledge, the present study is the first one to provide a wide picture of the presence of EOCs not only in Gran Canaria but also in any one of the Canary Islands.

From these perspectives, the aims of the present research were as follows: (1) the evaluation of the occurrence of the selected EOCs in environmental samples during the period July 2016-April 2018 and summarization and assessment of the different methodologies developed for their sampling, identification, and quantification; and (2) to study the removal efficiency of some target compounds both in conventional and natural WWTPs.

The results obtained can provide valuable information about the presence and distribution of the target compounds in this geographical area. Analysis of these compounds in the selected matrices allows us to understand how they are distributed, from their input in the WWTP to their arrival in the marine environment. Moreover, considering the prevailing water scarcity of the Canary Islands, a sustainable wastewater treatment plan might be designed to maximize the reuse of the recovered wastewater in agriculture, parks and gardens, aquifer recharge, etc., provided the appropriate level of treatment is achieved.

\section{Material and Methods}

\subsection{Target Emerging Organic Pollutants}

EOCs comprise a large group of potentially mutagenic and carcinogenic compounds that can alter the endocrine system interfering with natural biological functions. These compounds include substances from diverse groups, such as steroid sex hormones, pharmaceuticals, and PCPs. In this study, we include some of the EOCs most commonly found in environmental samples. Specifically, we present an update of the occurrence of three selected families of EOCs (see Table 1) in environmental matrices from the Canary Islands (Spain), related to WWTPs and CWs, including UV filters and stabilizers, antineoplastic or cytostatic agents, and natural and steroid hormones.

Benzotriazole ultraviolet stabilizers (BUVSs) are widely used to protect against the damage caused by sunburn. They have two different applications: (1) in personal care products (PCPs) to protect skin, where they are added not only to sunscreens but also to lotions and cosmetics; (2) in different materials, such as plastics, to avoid degradation and decolouring [24-26]. Therefore, BUVSs can reach the environment not only through the effluents of WWTPs but also by means of the use of PCPs by the population. Once in the marine ecosystem, BUVSs can exert negative effects on organisms, especially related to their reproductive functions. These compounds are highly lipophilic, which means that they are likely to bioaccumulate in fatty tissue and undergo biomagnification $[27,28]$. In this manner, the occurrence of BUVSs has already been demonstrated in different levels of the trophic chain.

Cytostatic compounds or antineoplastic agents are drugs used in the fight against cancer. They reach wastewater via the excretion of treated patients. Thus, hospitals are considered to be the main input of cytostatic compounds, but at present, an increasing number of patients continue their treatment at home, so domestic wastewater is also considered a source of contamination. These compounds are designed to kill cells or inhibit cell mitosis; for that reason, all cells are negatively affected, not just the cancerous ones. Their presence and occurrence in the environment has been detected at very low concentrations; however, due to the means of action of these medicines, it is necessary to know their concentrations in wastewater, particularly when they are present in mixtures [29-32]. In addition, 
adverse effects have been detected in different organisms treated with low concentrations of these compounds [33,34].

Table 1. Physicochemical characteristics of the studied compounds.

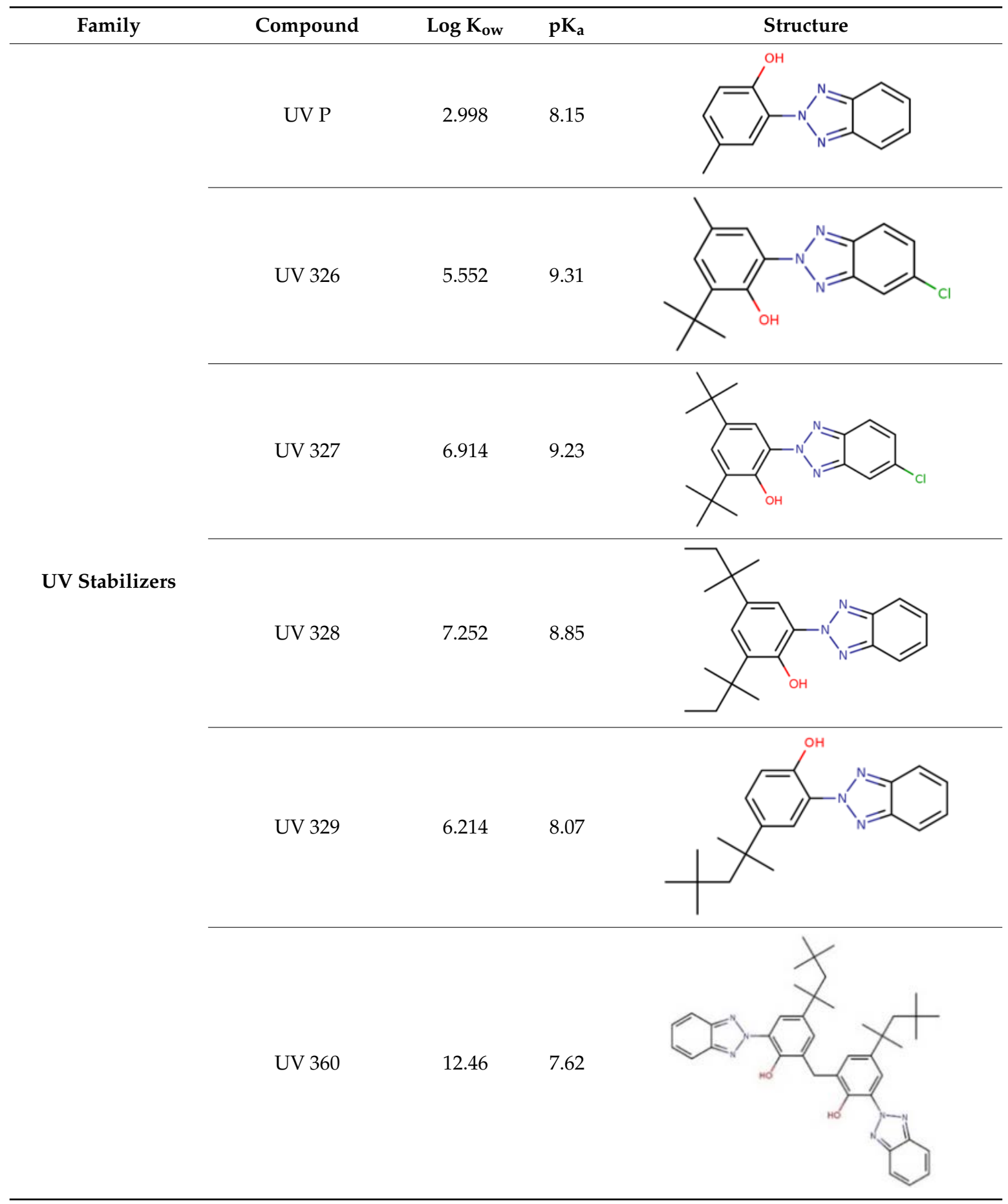


Table 1. Cont.

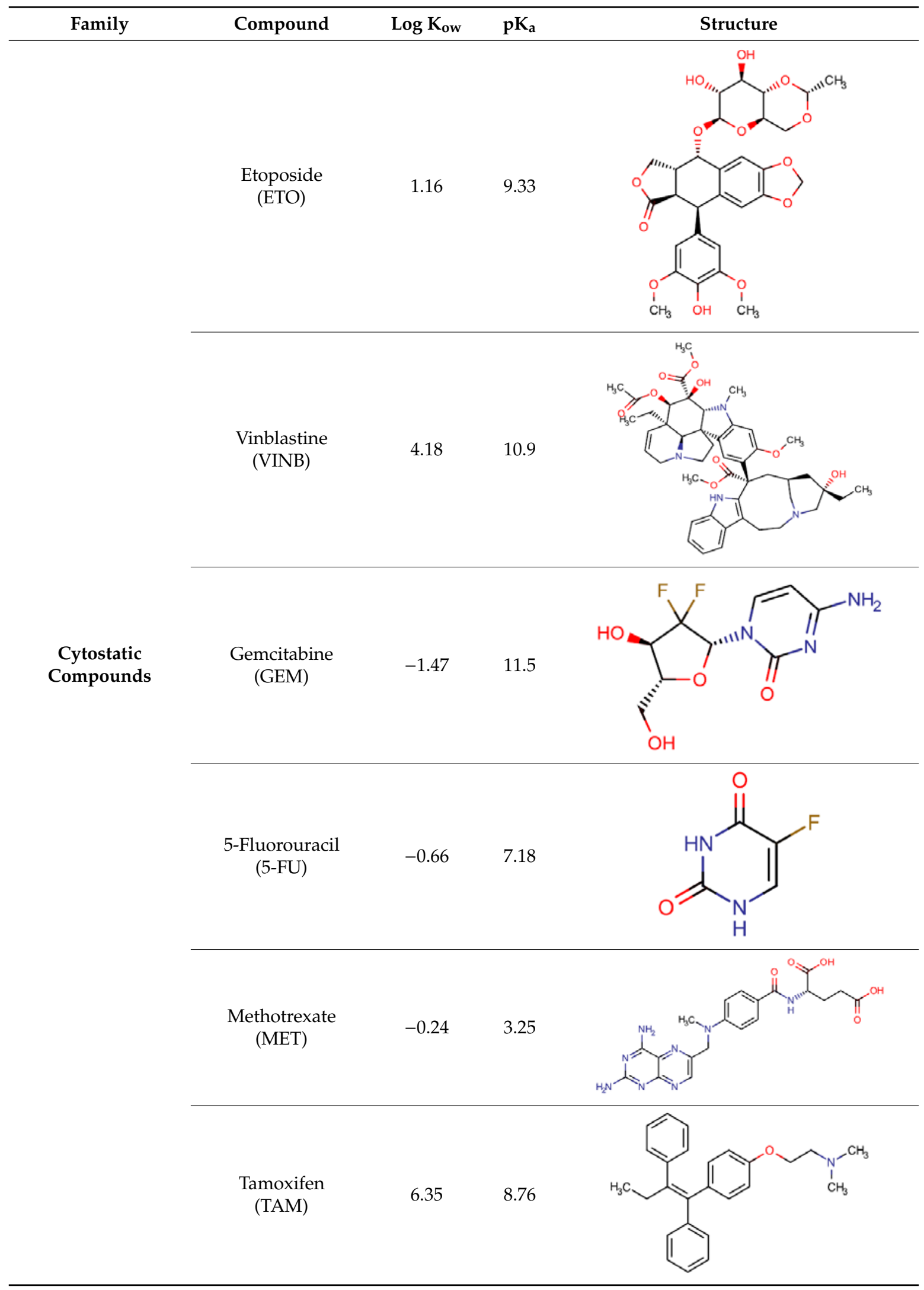


Table 1. Cont.

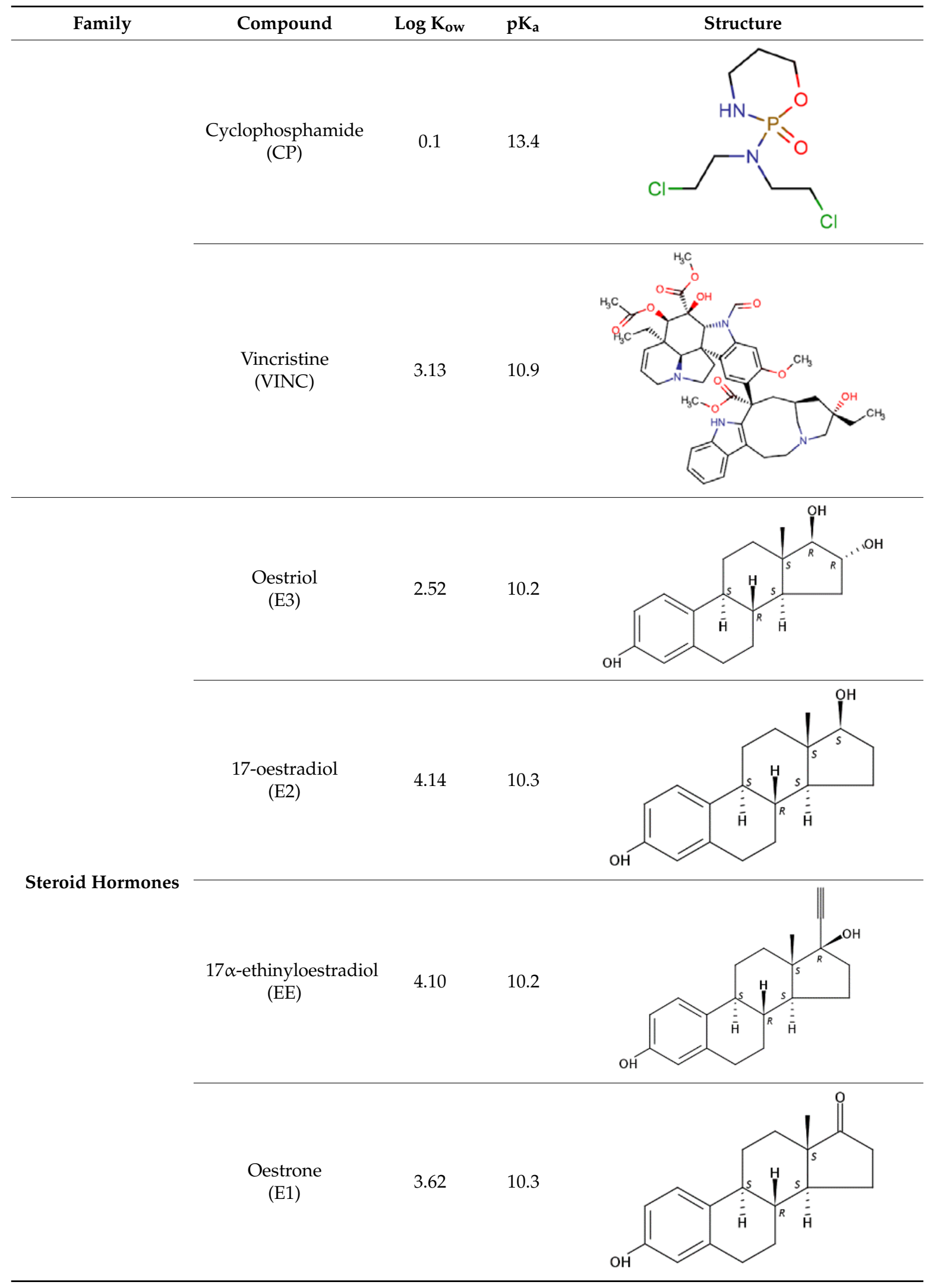


Table 1. Cont.

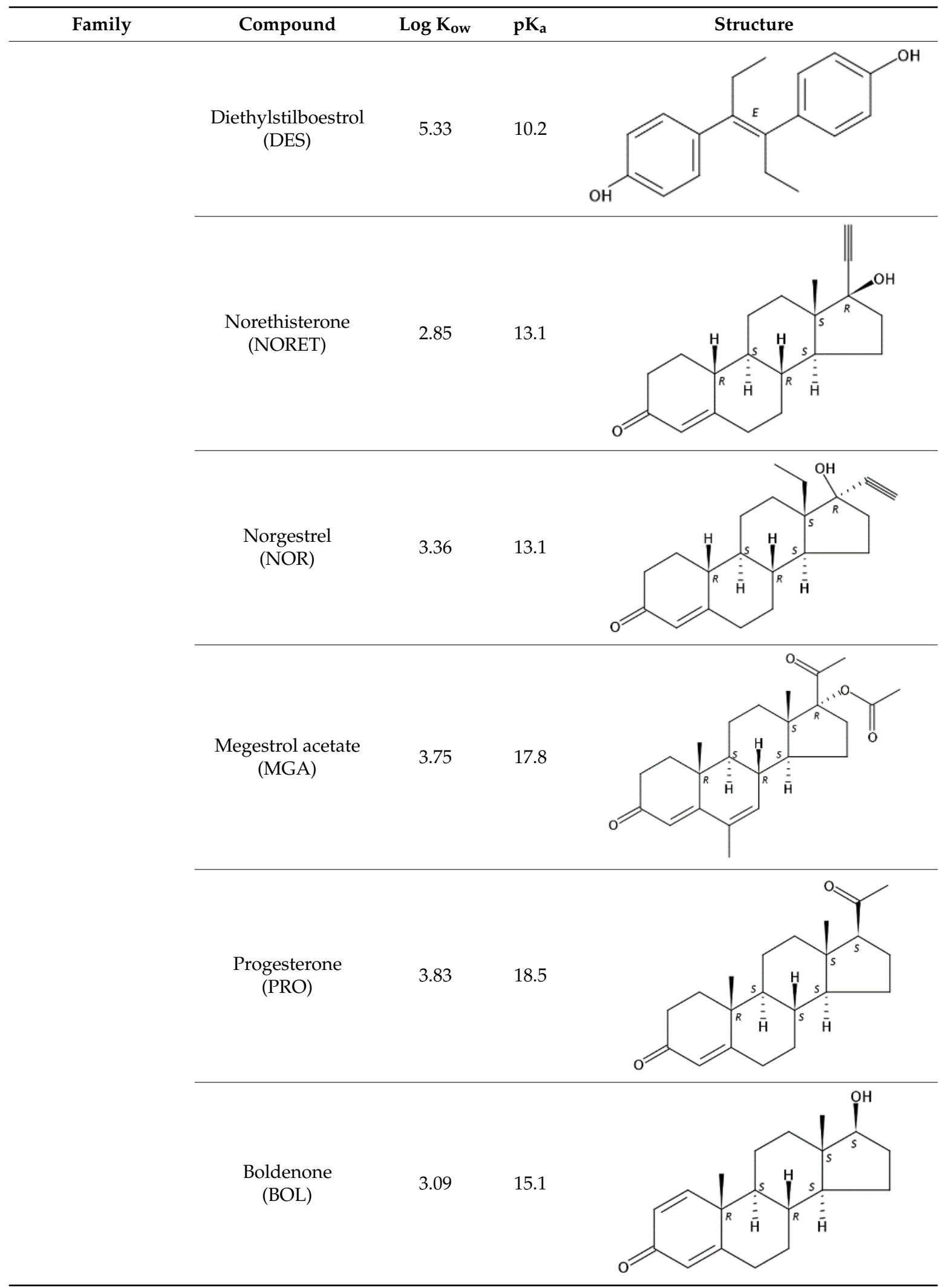


Table 1. Cont.

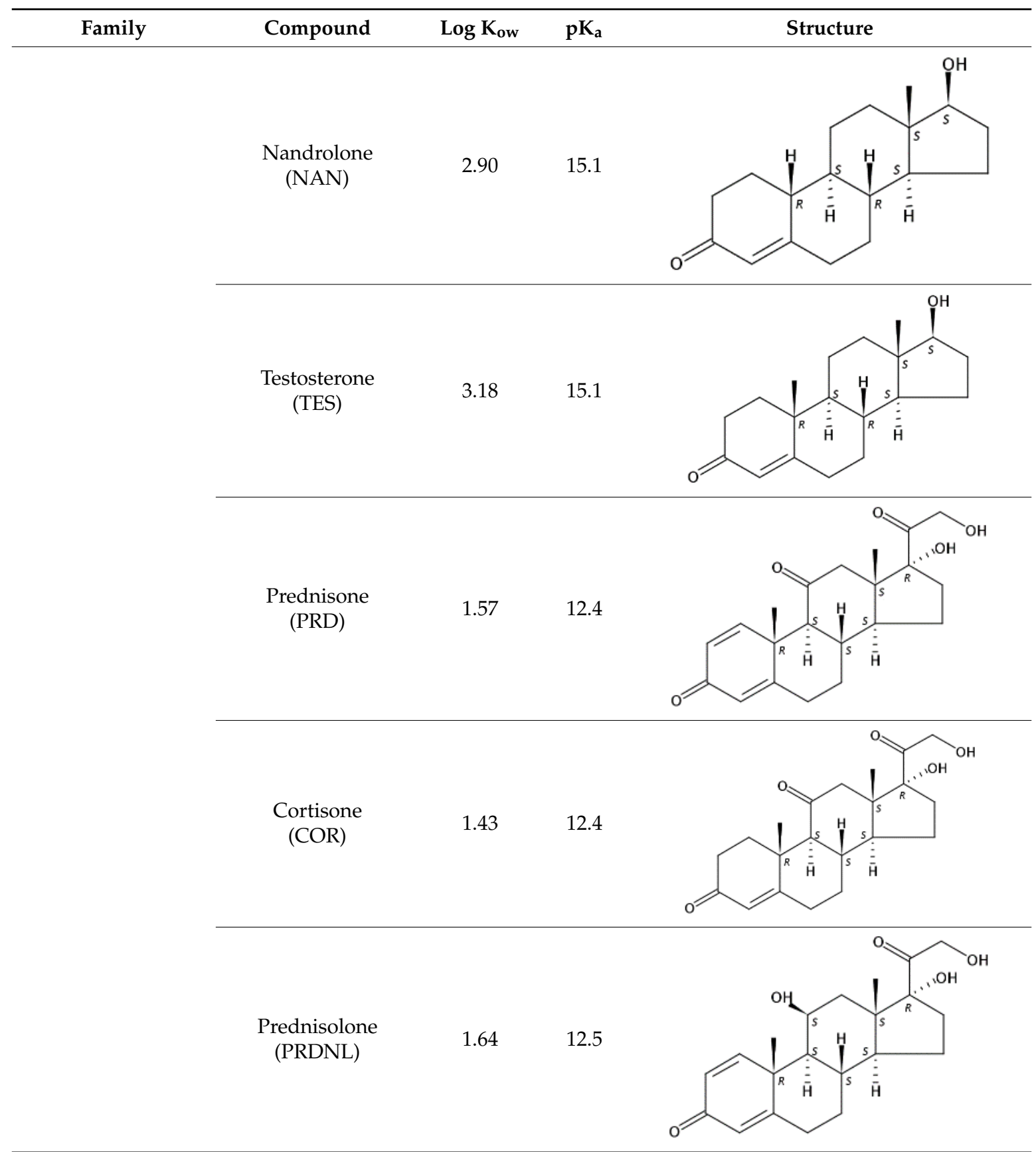

For UV stabilizers, $\log \mathrm{K}_{\mathrm{ow}}$ was obtained from the Ecological Structure Activity Relationships Predictive Model (ECOSAR) Program, U.S. Environmental Protection Agency (EPA) and $\mathrm{pK}_{\mathrm{a}}$ values obtained from scifinder.cas.org, except for the $\mathrm{pK}_{\mathrm{a}}$ values of megestrol acetate and progesterone and cytostatic compounds, for which the data were obtained from chemicalize.com.

Steroid hormones are biologically active compounds that control many metabolic processes, both genomic and non-genomic, in mammals. Steroid hormones have become one of the most prescribed drugs because they can be used to treat different illnesses and disorders of the reproductive apparatus and other organic systems. Naturally produced hormones as well as synthetic ones used as pharmaceuticals are being excreted via faeces and urine, and for this reason, the entrance of these compounds is continuous, which produces an effect of pseudo-persistence in the environment [35]. Steroid hormones could produce adverse effects in aquatic biota at very low concentrations, even at $\mathrm{g} \mathrm{L}^{-1}$. For this reason, three steroid hormones with high potential capability to disrupt the endocrine system of aquatic organisms, 
i.e., oestrone, $17 \beta$-oestradiol, and $17 \alpha$-ethinyloestradiol, have been added to the watch list of the Water Framework Directive [36] in order to determine their presence in the European environment and the effects produced in the exposed biota. Many studies have reported toxic effects in aquatic biota of low concentrations of steroid hormones, such as sexual [37], physiological, or behavioural changes [38-40].

Therefore, the interest in the sensitive determination of these compounds in environmental samples has increased in recent years, integrating sample preparation and analytical approaches for quantifying these families of EOCs in environmental samples. The need to determine low concentrations of these substances, as well as matrix complexity, requires the development analytical methods with high sensitivity, selectivity, and resolution that can be applied to soil, sediment, water, and other environmental samples. In this context, recent tendencies are related to the application of green approaches that reduce the use of organic solvents and the automation of sample preparation [41].

Moreover, chromatographic techniques have become the analytical systems of choice because they enable identification of individual analytes of interest. However, the quantification of these compounds in complex environmental samples presents great difficulties. Therefore, it is necessary to apply suitable extraction and pre-concentration procedures to samples to isolate and pre-concentrate the analytes prior to their determination.

To study the presence of target compounds, wastewater, seawater, sediment, sludge, and fish samples were taken for two years (from July 2016 to April 2018) every three months.

\subsection{Samples Related to Wastewater Treatment Plants}

\subsubsection{Water}

Influent and effluent wastewater samples were collected from five WWTPs of the island of Gran Canaria. Table 2 presents the characteristics of four of them, which apply conventional depuration systems, mainly based on activated sludge. WWTP1 is the smaller one, and it is located on the north; while WWTP2 is the biggest treatment plant of the island, located in the capital city, Las Palmas de Gran Canaria. WWTP3 and WWTP4 are placed on the east and south of the island, respectively, and have an intermediate size, treating water from touristic areas, especially WWTP4. In addition, samples from the effluent of one of the main hospitals of the island were also taken since hospitals are considered to be the main entrance of cytostatic compounds into the sewage system.

Table 2. General characteristics of the selected conventional wastewater treatment plants (WWTPs).

\begin{tabular}{cccc}
\hline WWTP & Treatment Applied & Design Flow $\mathbf{( m}^{\left.\mathbf{3} \cdot \mathbf{d}^{-\mathbf{1}}\right)}$ & Population Equivalent (PE) \\
\hline 1 & Membrane bioreactor & 750 & 6000 \\
2 & Activated sludge & 52,200 & 400,000 \\
3 & Activated sludge and reverse osmosis & 12,000 & 100,000 \\
4 & Activated sludge & 12,500 & 100,000 \\
\hline
\end{tabular}

Finally, a natural wastewater treatment system situated at the University Campus was also studied (WWTP5). This system is formed by a facultative pond and a horizontal-flow CW as a refining system and receives water from different university facilities. It has been used for the last 20 years, achieving good removal of conventional water quality parameters. Natural depuration systems are designed to treat wastewaters from small to medium size $(<2.000$ population equivalent, $\mathrm{PE})$ communities with low or nil energy consumption. Hence, their environmental impact is lower than that of conventional systems, and they are also aesthetically pleasant. The experimental WWTP5 is fully covered with plants, so as the facultative pond could be considered as a macrophyte pond. The horizontal-flow $\mathrm{CW}$ comprises 3 channels in series. The first two channels are surface flow, and the last one is a subsurface-flow channel. Two gravel filters are located between the pond and the first channel and between the surface-flow channels. Three sampling points were established in the pond influent, the pond effluent, and the CW effluent. Figure 1 shows the WWTP5 layout as well as the sampling points. 


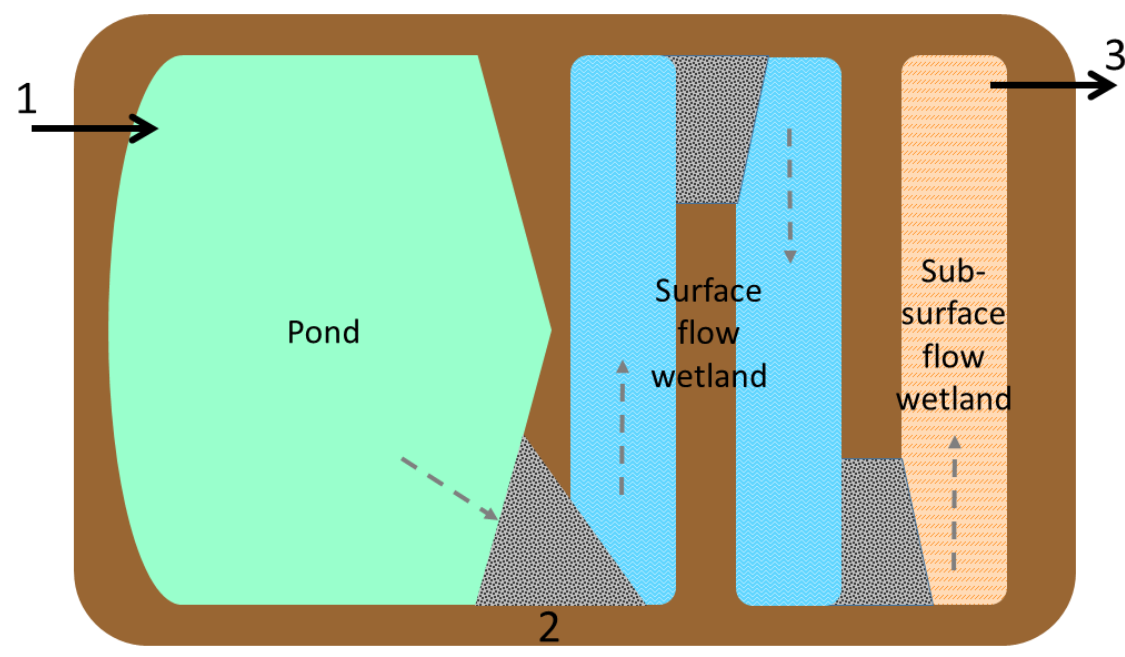

Sampling points:

Water flow direction: $----\rightarrow$

1: Influent

2: Pond's effluent

3: Constructed wetland effluent

Figure 1. Layout of WWTP5 and sampling points.

Seawater samples from the marine outfall areas, corresponding to WWTP2, WWTP3, and WWTP4 effluents were also analysed.

Water samples (seawater and wastewater) were taken in glass amber bottles, acidified with hydrochloric acid to a $\mathrm{pH}$ in the range of $2.5-3.5$, and stored at $4{ }^{\circ} \mathrm{C}$. Before extraction, all samples were filtered through a $0.65 \mu \mathrm{m}$ filter.

\subsubsection{Sludge and Sediments}

Sludge samples were obtained from WWTP2, WWTP3, and WWTP4, which use activated sludge treatment. Sludge samples were taken after dehydration. The samples to determine BUVSs were taken in 2013, while the cytostatic compounds were monitored every three months from July 2016 to April 2018.

Sediment samples were collected by a professional diver next to the discharge of marine outfalls corresponding to WWTP2, WWTP3, and WWTP4, which are situated at depths of 15-20 m.

Sludges and sediments were taken in glass bottles, freeze-dried, sieved through a $0.3 \mathrm{~mm}$ sieve, and stored at $4{ }^{\circ} \mathrm{C}$ or frozen until analysis.

\subsection{Bioindicators}

Three species of fish (Sphoeroides marmoratus, Sphyraena viridensis, and Boops boops) were caught close to the same marine outfalls (WWTP2, WWTP3, and WWTP4) by a professional underwater fisherman. Samples were instantaneously frozen. Before analysis, samples were manually separated into muscle and viscera prior to the lyophilization procedure. Each part was then triturated, sieved through $0.3 \mathrm{~mm}$, and stored at $4{ }^{\circ} \mathrm{C}$ until analysis.

\subsection{Analytical Procedures}

Experimental designs were used to select the best conditions for each family of pollutants, in order to take into account not only the influence of each parameter on the extraction efficiency but also the 
interaction between them. The analytical parameters were also validated for the developed methods in every case.

For wastewater and seawater, the most employed extraction technique for liquid environmental samples, solid-phase extraction (SPE), was selected for the determination of target analytes. The wide range of different sorbents allows for the application of SPE to different analytes.

Automatization of the conventional procedure, namely, on-line SPE, was also employed for some of the families of compounds. It was coupled with ultra-high-performance liquid chromatography (UHPLC), and in this case, the elution was performed with the mobile phase used in the chromatographic system. The established extraction conditions in water samples for different families of compounds are presented in Supplementary Table S1.

For the determination of BUVSs in wastewater and seawater samples, SPE in on-line mode was selected, using the conditions shown in Supplementary Table S1. The achieved limits of detection (LOD) were in the range of $0.6-4.1 \mathrm{ng} \mathrm{L}^{-1}$ with a relative standard deviation (RSD) between $6.2 \%$ and $10 \%$ [42].

Regarding cytostatic compounds, off-line SPE was used to extract the mixture of eight cytostatic compounds listed in Table 1 from wastewater and seawater samples. Extraction conditions for different water samples are shown in Supplementary Table S1. Under the optimal conditions, 5-fluorouracil was not retained, and gemcitabine was poorly extracted. Consequently, both compounds were excluded from the analyses. For wastewater samples, intra-day and inter-day RSD values less than $10 \%$ and $11 \%$, respectively, were obtained. For seawater samples, the obtained RSD values were less than $12 \%$ and $16 \%$, respectively. The obtained recoveries were $45-136 \%$ in the influent, $47-149 \%$ in the effluent of wastewaters, and $64-114 \%$ in the seawater for six compounds (etoposide, vinblastine, methotrexate, tamoxifen, cyclophosphamide and vincristine) at different concentrations levels. The matrix effect results exhibited suppression of the signal up to $99.85 \%$ in the influent and up to $99.32 \%$ in the effluent and an enhancement of the signal up to $100.8 \%$ in seawater, which also presented a suppression of the signal up to $87.93 \%$ for some compounds. Finally, an LOD was established at $1.68-104 \mathrm{ng} \mathrm{L}^{-1}$ in the influent, 2.66-77.9 $\mathrm{ng} \mathrm{L}^{-1}$ in the effluent, and 0.95-5.14 $\mathrm{ng} \mathrm{L}^{-1}$ in seawater [43].

To extract target hormonal compounds, SPE on-line mode was selected with optimal conditions shown in Supplementary Table S1. Using this method, very low LOD values were achieved, between 0.5 and $13.2 \mathrm{ng} \mathrm{L}^{-1}$, which are highly appropriate for the determination of steroid hormones in water samples. The achieved recoveries were satisfactory, as was the repeatability of the method, which exhibited RSDs less than 15\% [44].

Microwave-assisted extraction (MAE) has been employed for solid samples (sediment, sludge, and fish). Variables that affect the process were evaluated through different experimental designs to find the optimal extraction conditions for the following parameters: sample amount, power and time of microwave system, and extractant agent. The best extraction conditions in solid samples for different families of compounds are reported inSupplementary Table S2.

After the extraction of UV stabilizers from sludges and sediments in the optimal conditions, a subsequent on-line SPE was implemented to purify the extract. The developed method offers LODs from 53.3 to $146 \mathrm{ng} \mathrm{kg}^{-1}$. The recoveries were between $46.1 \%$ and $83.9 \%$ for sludges and between $50.1 \%$ and $87.1 \%$ for sediments, with relative standard deviations in the ranges of $7.8-15.5 \%$ and $8.83-16.3 \%$, respectively [45].

In the case of cytostatic compounds in sediments and sludge, optimal conditions permit the extraction of gemcitabine, cyclophosphamide, etoposide, and tamoxifen from the mix of selected compounds. After extraction, samples were dried with $\mathrm{N}_{2}$ and reconstituted in $\mathrm{MeOH}$ before analysis. The recovery in sediments ranged from $10.0 \%$ to $105 \%$, while in sludge, it ranged from $65.0 \%$ to $122 \%$. Intra-day and inter-day RSD values lower than $12.8 \%$ and $17.8 \%$, respectively, were obtained in sediment, whereas intra-day and inter-day RSD values lower than $14.5 \%$ and $16.4 \%$, respectively, were obtained in sludges. Gemcitabine presented a high signal suppression due to the matrix in both matrices (up to $94 \%$ ). Cyclophosphamide and etoposide presented a signal suppression up to $49.0 \%$ in 
sediment and up to $72.0 \%$ in sludge; while tamoxifen was not affected by the matrix in sediment and had a suppression of the signal in sludge of approximately 54.0\%. LOD values ranging from 0.10 to $87.5 \mathrm{ng} \mathrm{g}^{-1}$ were obtained in sediment, and LOD values ranging from 0.40 to $79.8 \mathrm{ng} \mathrm{g}^{-1}$ were obtained in sludges [46].

To perform the extraction of steroid hormones, optimal conditions were applied. After that, the extract was reconstituted with $\mathrm{MeOH}$. This optimized method achieved great recovery efficiencies, above $70 \%$, with great reproducibility. The extraction method coupled to UHPLC-MS/MS provided detection limits that ranged from 1.1 to $7.9 \mathrm{ng} \mathrm{g}^{-1}$ [47].

For fish samples, the extracts resulting from the application of the optimal conditions for the extraction of UV stabilizers (Supplementary Table S2) were passed through a phospholipid removal cartridge in order to remove interferences. The obtained recoveries were in the range of $13.1-75.4 \%$ for muscle and $22.9-72.8 \%$ for viscera. Values of precision from $0.21 \%$ to $6.06 \%$ were obtained, and the LODs were in the range of $0.34-2.87 \mathrm{ng} \mathrm{g}^{-1}$ for muscle and $0.60-2.43 \mathrm{ng} \mathrm{g}^{-1}$ for viscera.

Cyclophosphamide, tamoxifen, vinblastine, and vincristine were extracted from fish using the optimal conditions (Supplementary Table S2). After that, extracts were passed through a phospholipid and protein removal cartridge in order to clean the sample dried and reconstituted in $\mathrm{MeOH}$. The intra-day and inter-day RSD values were below $20.5 \%$ in all cases at all concentration levels tested. The recovery and matrix effects were tested in the two tissues analysed, i.e., muscle and liver. Cyclophosphamide and tamoxifen presented recovery values ranging from $74 \%$ to $122 \%$ for both tissues, with a high suppression of the signal due to the matrix in liver samples. Regarding vinblastine and vincristine, the recovery values were between $53 \%$ and $113 \%$, with an enlargement of the signal in both matrices. The LOD values reached for both matrices were between 0.5 and $1.3 \mathrm{ng} \mathrm{g}^{-1}$ for cyclophosphamide and tamoxifen and between 46 and $536 \mathrm{ng} \mathrm{g}^{-1}$ for vinblastine and vincristine [48].

Finally, extraction conditions of hormones from the different fish tissues are shown in Supplementary Table S2. After applying the MAE procedure, the extracts were filtered to remove phospholipids and other impurities present in fish tissue. The method exhibited LODs between 0.14 and $49.0 \mathrm{ng} \mathrm{g}^{-1}$, recoveries in the range of $50 \%$, and good repeatability (with RSDs less than $20 \%$ for all compounds) [49].

All determinations of target compounds were performed using an ultra-high-performance liquid chromatography tandem mass spectrometry (UHPLC-MS/MS). An ACQUITY UPLC system equipped with a triple quadrupole detector with an electrospray ionization (ESI) interface controlled by the MassLynx Mass Spectrometry software was used. The system consisted of a 2777 autosampler, a Binary Solvent Manager, and a column manager, all from Waters Chromatography (Barcelona, Spain). The detection and mass spectrometer parameters were optimized using standard solutions of each compound and are presented in Supplementary Tables S3 and S4, respectively.

The chromatographic separation conditions for each family are summarized in Supplementary Table S5. The injection volume was $10 \mu \mathrm{L}$ in all determinations.

\section{Results and Discussion}

\subsection{Samples Related to Wastewater Treatment Plants}

\subsubsection{Water}

Figure 2 shows the range of concentration of the selected EOCs in wastewater (influent and effluent samples). UV stabilizers were found at all locations in concentrations between 13.12 and $1933 \mathrm{ng} \mathrm{L}^{-1}$ [50]. In general, the concentrations measured in the influent samples were greater than those found in the effluents, most probably due to the adsorption of the compounds onto the suspended solids during the treatment because of their low solubility and high $\log \mathrm{K}_{\mathrm{ow}}$. However, no significant differences were observed in the effluents according to the treatment employed. The frequency of detection was lower in the largest WWTPs; however, when the results obtained are normalized according to the volume of treated water and the equivalent population of each WWTP, quite homogeneous results are 
observed in terms of the measured concentrations. UV-329 was the compound most frequently found, appearing in 33\% of the influent samples (in the range of $106-1933 \mathrm{ng} \mathrm{L}^{-1}$ ) and in $10 \%$ of the effluent samples (in the range of 49.54-570.9 $\mathrm{ng} \mathrm{L}^{-1}$ ), which demonstrated its incomplete elimination in the treatment system. Concentrations obtained in the influent samples were higher than those published by other authors, for example, $85.0 \mathrm{ng} \mathrm{L}^{-1}$ measured by Carpinteiro et al. [51] or $414 \mathrm{ng} \mathrm{L}^{-1}$ reported by Liu et al. [52]. Regarding the samples from WWTP effluents (found in the range 28.80-570.9 $\mathrm{ng} \mathrm{L}^{-1}$ ), their concentrations of BUVSs were in the same order of magnitude as others found in the literature (e.g., $125 \mathrm{ng} \mathrm{L}^{-1}$ [52]). However, no compound was detected in the natural depuration system, probably because it only receives water from a small part of the campus, and these personal care products are normally used at home.

(a)

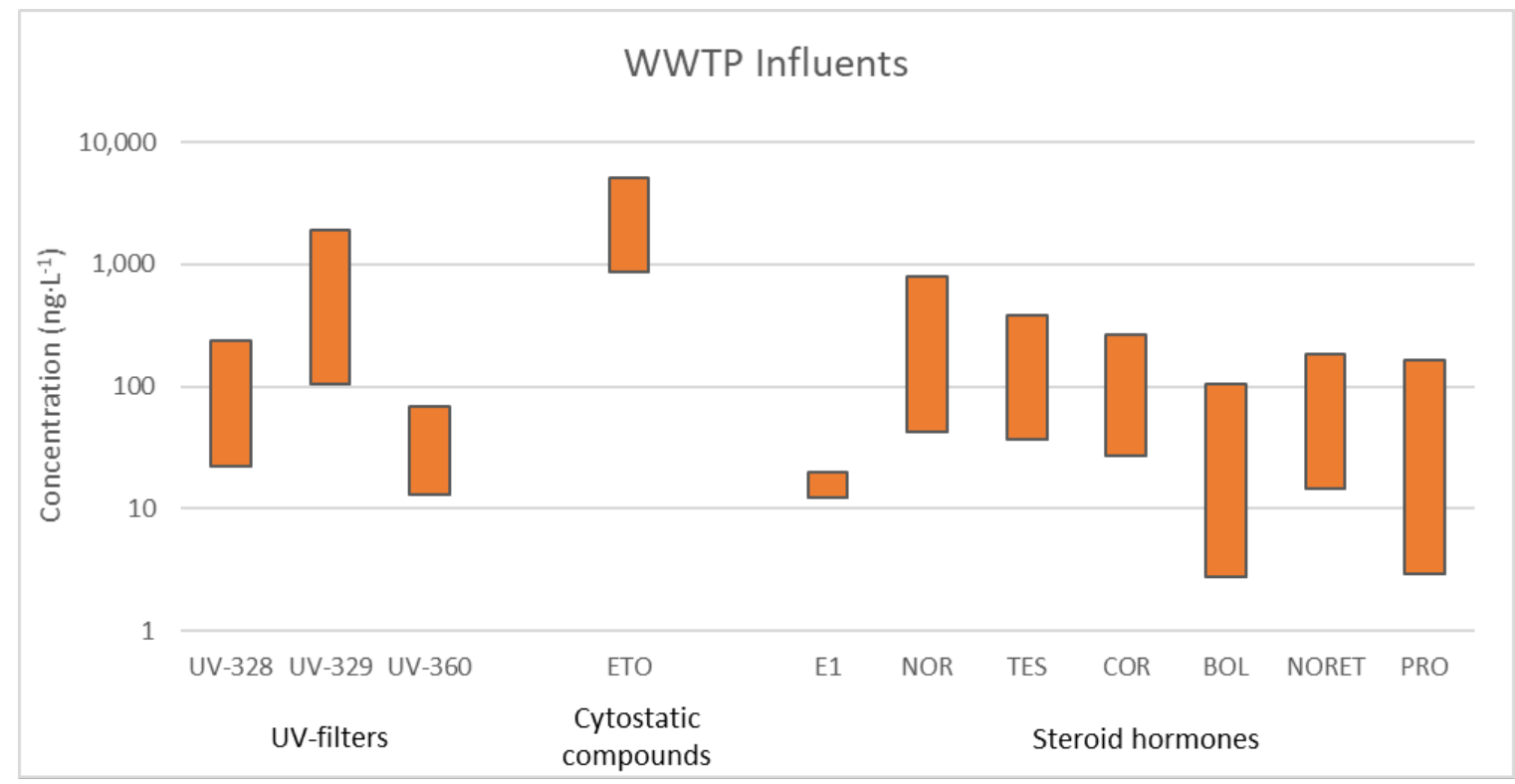

(b)

\section{WWTP Effluents}

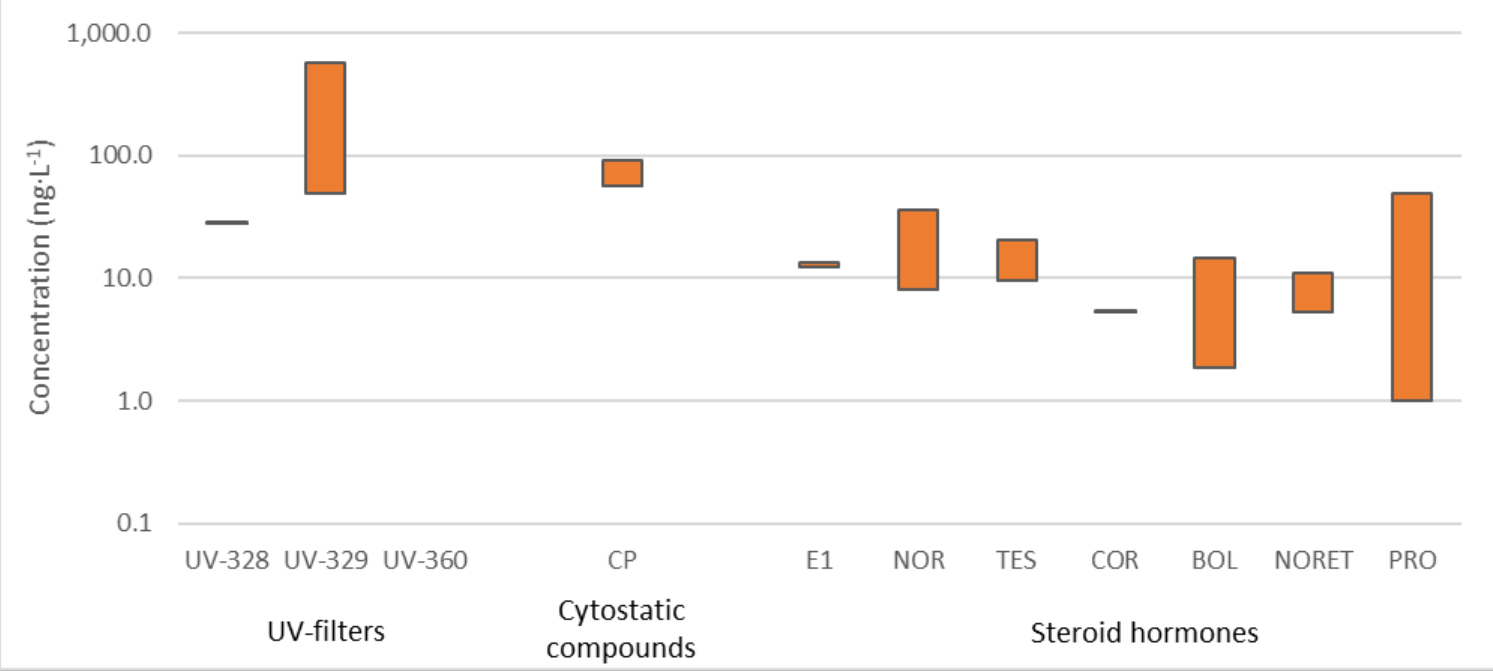

Figure 2. Range of concentrations (ng L $\mathrm{L}^{-1}$ ) for detected emerging pollutants in wastewater from (a) influent points and (b) effluent points. 
Cytostatic compounds were detected mainly in hospital effluents, with detection of the compound etoposide at concentrations between 375.8 and $619.9 \mathrm{ng} \mathrm{L}^{-1}$, cyclophosphamide at $1218 \mathrm{ng} \mathrm{L}^{-1}$, vincristine at $1851 \mathrm{ng} \mathrm{L}^{-1}$, and vinblastine at $1835 \mathrm{ng} \mathrm{L}^{-1}$. Regarding cytostatic compounds in WWTPs, only two of them were detected. Etoposide was detected in all the analysed wastewater samples but always in the influent, which may mean that this compound is degraded during the process. Its concentration was slightly high, with values from 874.9 to $5141 \mathrm{ng} \mathrm{L}^{-1}$. Cyclophosphamide was detected only in WWTP2 and always in the effluent in concentrations ranging from 55.94 to $91.25 \mathrm{ng} \mathrm{L}^{-1}$. Etoposide was detected on very few occasions, probably because it is degraded during the water treatment process [53]. However, it was detected in hospital effluents in concentrations of up to $380 \mathrm{ng} \mathrm{L}^{-1}$ [54], in the same range as those found in the present work. Cyclophosphamide is the most studied compound in wastewaters, which was detected on several occasions in treatment plants at concentrations up to $13,100 \mathrm{ng} \mathrm{L}^{-1}$ [55]. Nevertheless, the concentrations of cyclophosphamide in wastewaters detected in other studies are much lower, which is in accordance with the concentrations of the present study $[56,57]$.

A deep study of the presence and removal of steroid hormones was conducted in WWTP5, the natural treatment system, to compare its removal efficiency with those of conventional treatments, a topic that has been thoroughly studied in the scientific literature. With the goal of determining the contribution of the two components of the natural system (pond and CW in series), the steroid hormone concentrations were analysed in three sampling points: pond influent and effluent and CW effluent. Because of its discontinuous working regime, the sampling campaign of the natural system was different from that of the conventional WWTPs. In WWTP5, eight hormones from the four steroid hormone families were detected in the three sampling points. The concentrations of all hormones decreased as the influent made its way through the system. The concentrations varied from 17.3 to $247.7 \mathrm{ng} \mathrm{L}^{-1}$ in influent samples to 8.1 to $22.1 \mathrm{ng} \mathrm{L}^{-1}$ in the final effluent samples. These concentrations are similar to those from other studies in natural treatment systems. In fact, a survey conducted in Tanzania in a waste stabilization pond detected steroid hormone concentrations ranging from 0.1 to $445 \mathrm{ng} \mathrm{L}^{-1}$ in influent samples and up to $45 \mathrm{ng} \mathrm{L}^{-1}$ in effluent samples [58]. The same behaviour was observed in a study in China where steroid hormones were detected in a CW at the same concentration levels of this study [59]. The detected concentrations were also in accordance with other surveys conducted in conventional wastewater treatments in Gran Canaria [44]. The components of the natural treatment achieved similar removal efficiencies, ranging from $24.1 \%$ to $100 \%$ for the pond, and from $57.1 \%$ to $100 \%$ for the $\mathrm{CW}$. Overall, the removal efficiency of the whole purification system was over $76 \%$ for all hormones, reaching values over $95 \%$ for oestriol, testosterone, cortisone, and boldenone [18].

The analysis of UV stabilizers in seawater allowed their detection both at depth and surface of the marine outfall (Figure 3). Again, UV-329 was the most frequently detected compound, appearing at all the locations at concentrations between 67.5 and $859.0 \mathrm{ng} \mathrm{L}^{-1}$ [50]. The frequency of detection was higher in the outfall of WWTP4, located in the most touristic part of the island. Moreover, UV stabilizers were sometimes measured in surface samples but not in deep ones. This result suggests that their presence was due to the direct use of PCPs on nearby beaches and rapid sorption onto organic surfaces.

In seawater samples, no cytostatic compounds were detected [43]. Similarly, no hormones were detected in these samples, probably due to the low concentration levels of steroid hormones in effluent samples and the effect of dilution when discharged into the sea.

\subsubsection{Sludge and Marine Sediments}

Considering the physical-chemical properties of emerging pollutants, a large fraction of the pollutants removed from wastewaters is finally accumulated in the sludge. Therefore, the protocols for sludge control and management are equal to or more important than those applied to waters, even more so if the sludge is intended to be used in agriculture. Furthermore, if treated wastewater is released into the ocean through marine outfalls, the most non-polar compounds could also accumulate 
in the near sediments instead of remaining in the liquid phase. For this reason, assessment of emerging pollutants in these types of samples is essential.

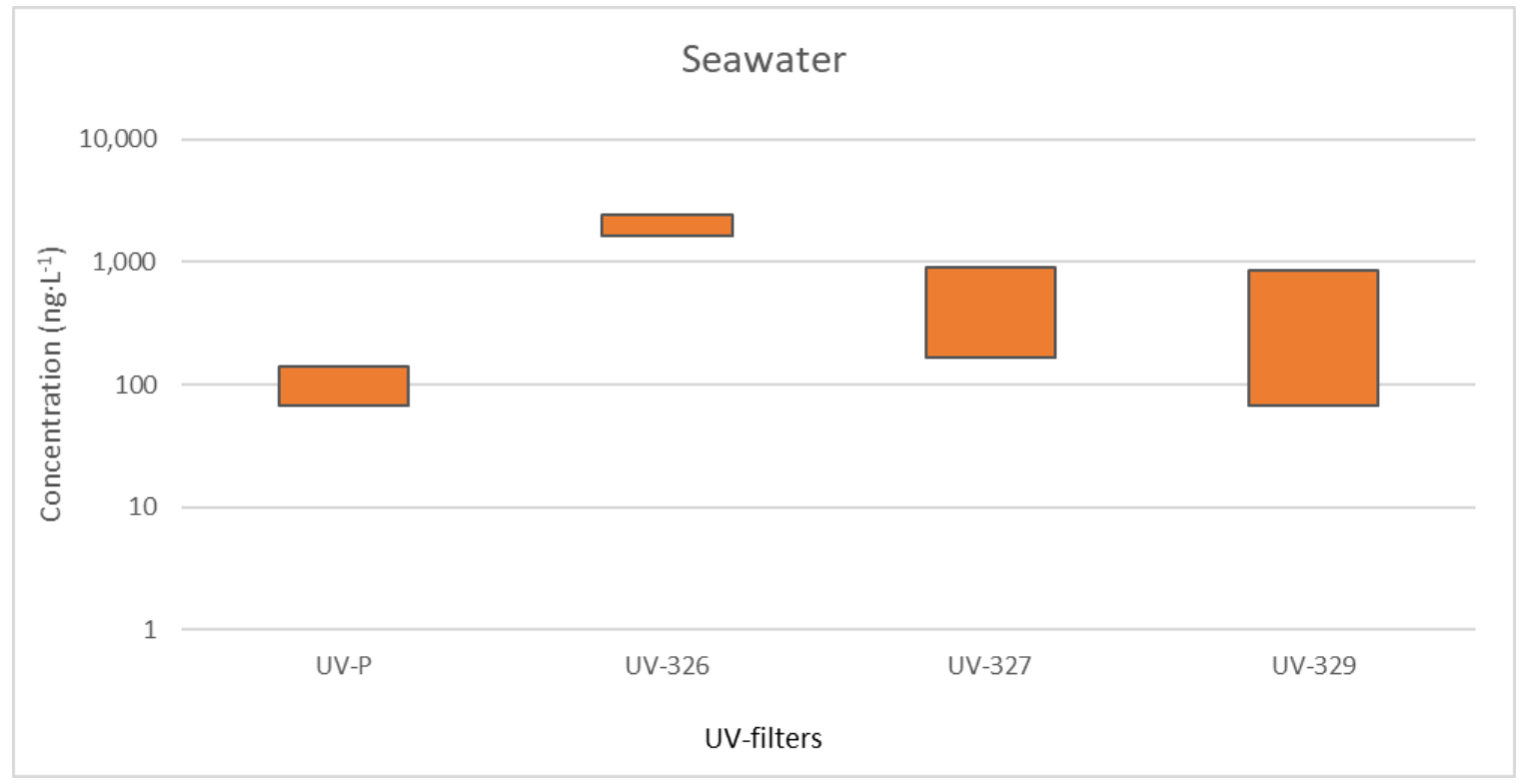

Figure 3. Range of concentrations $\left(\mathrm{ng} \mathrm{L}^{-1}\right)$ for detected benzotriazole UV stabilizers (BUVSs) in seawater.

Two UV stabilizers, UV-328 and UV-360, were detected in sludge from three different WWTPs (Figure 4). The measured concentrations of UV-328 were in the range of 0.94 (WWTP4) to $12.2 \mathrm{ng} \mathrm{g}^{-1}$ (WWTP1). UV-360 was found between $2.30 \mathrm{ng} \mathrm{g}^{-1}$ (WWTP2) and $6.32 \mathrm{ng} \mathrm{g}^{-1}$ (WWTP1) [45]. It should be noted that the analysis of BUVSs was not part of the temporal monitoring, so more data are needed to obtain more reliable conclusions about their presence in sludge.

Regarding target hormones, only four compounds ( $17 \alpha$-ethinyloestradiol, 17 $\beta$-oestradiol, norgestrel, and cortisone) were detected in sludge samples from WWTP1, WWTP2, and WWTP3 in an assessment carried out before the sampling period (see Figure 4). In all samples, 17 $\beta$-oestradiol was detected below the quantification limits, while cortisone was only detected in WWTP1 sludge. Norgestrel and 17 $\alpha$-ethinyloestradiol were detected in WWTP1, WWTP2, and WWTP3 sludge samples, and for both compounds, the highest concentrations were detected in WWTP1, probably because of the hydrophobic properties of membrane bioreactor sludge, which results in better sorption of the hormones onto sludge. For WWTP2 and WWTP3 sludge samples, the concentrations of $17 \alpha$-ethinyloestradiol ranged from 31.5 to $315 \mathrm{ng} \mathrm{g}^{-1}$, while the concentrations of norgestrel ranged from 430 to $874 \mathrm{ng} \mathrm{g}^{-1}$. These two compounds are the main ingredients in some contraceptive pills, and both present similar octanol-water partition coefficient values (greater than 3), which could explain their presence in sludge because of their similar adsorption behaviours [47].

UV stabilizers were also measured in marine sediment samples taken nearby the outfalls of sewage. UV-328 and UV-360, the most non-polar compounds, were identified in almost all the sampling periods in concentration ranges of 347.2-1788 $\mathrm{ng} \mathrm{kg}^{-1}$ dry weight (dw) (a detection frequency of $46 \%$ ) and 546.9-1862 $\mathrm{ng} \mathrm{kg}^{-1}(\mathrm{dw})$ (a detection frequency of 33\%), respectively. UV-329 and UV-326 were detected less frequently but at relatively high concentrations, up to 2162 and $9346 \mathrm{ng} \mathrm{kg}^{-1}(\mathrm{dw})$, respectively. In this case, the location most polluted was also the most touristic one [50].

Cytostatic compounds were not detected in these solid matrices, with their concentrations below the limit of detection. 
(a)

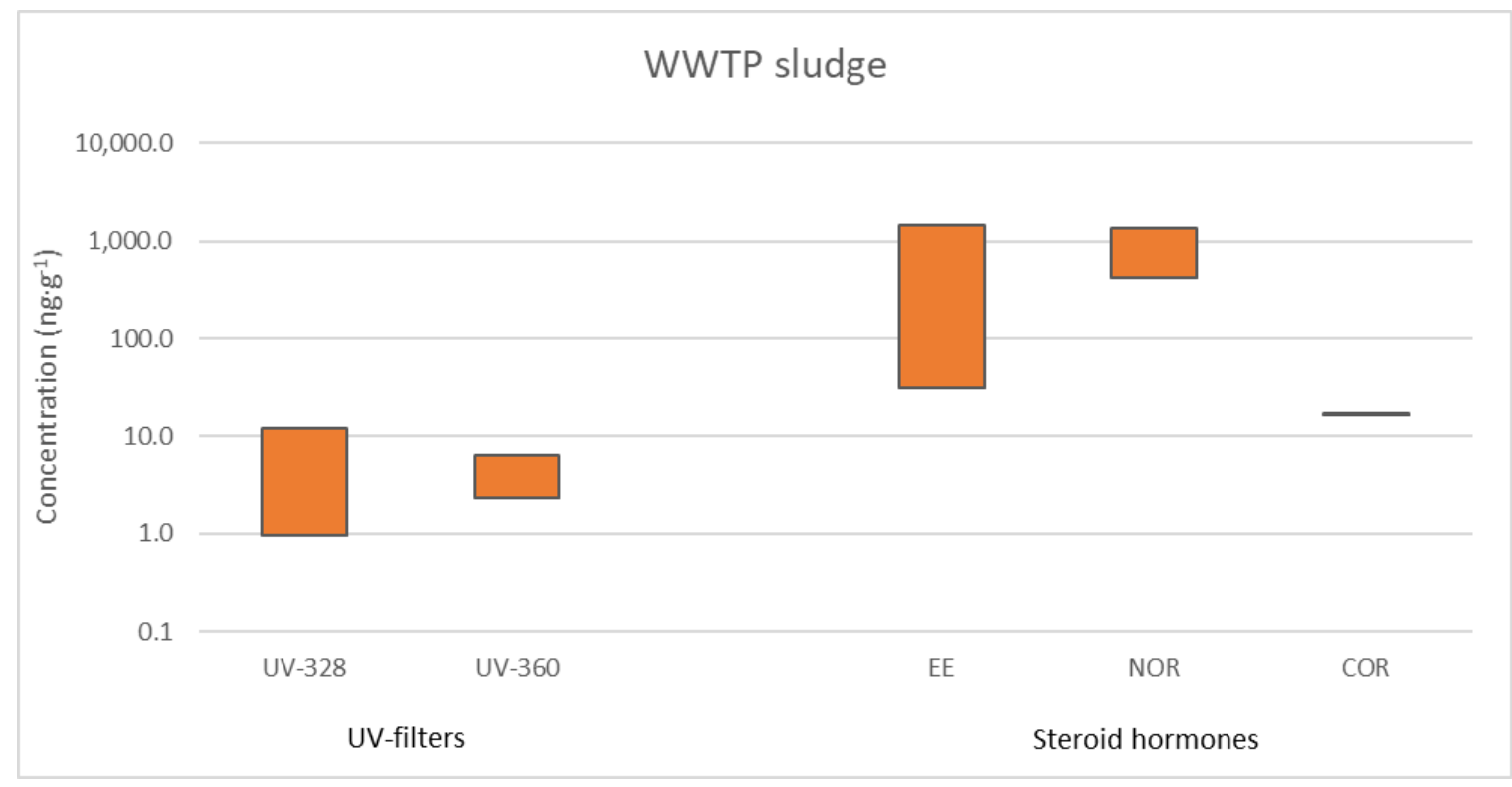

(b)

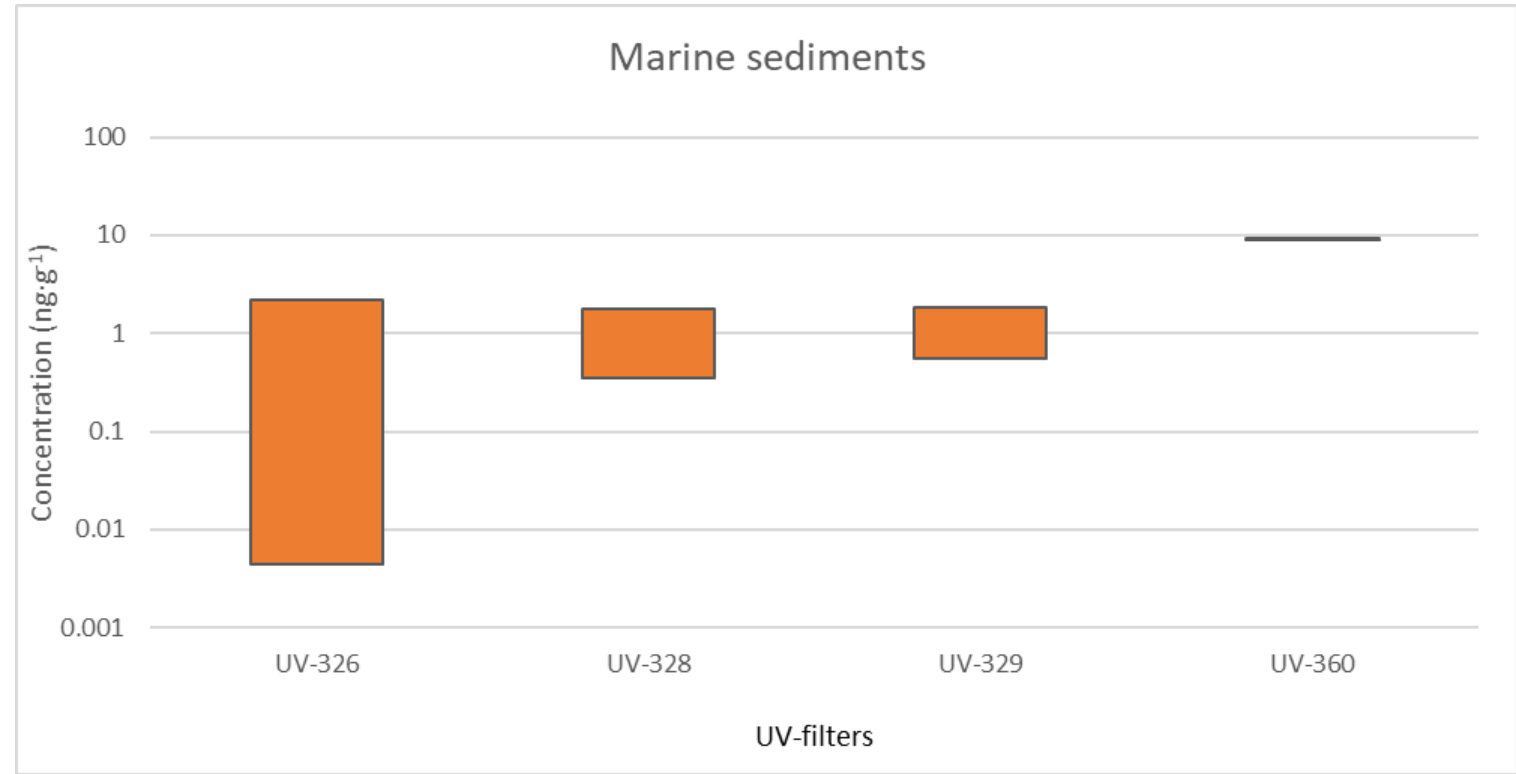

Figure 4. Range of concentrations $\left(\mathrm{ng} \mathrm{g}^{-1}\right.$ ) for detected emerging pollutants in (a) WWTP sludges and (b) marine sediments.

\subsection{Bioindicators}

The analysis of biota feeding near marine outfalls is required to determine whether the pollutants that are being discharged accumulate in the trophic chain and even undergo biomagnification. For that purpose, three common fish species of this habitat were monitored, as described in Section 2.3.

Three UV stabilizers, UV-326, UV 328, and UV 360, were detected in muscle in concentrations from 4.16 to $34.9 \mathrm{ng} \mathrm{g}^{-1}$ (Figure 5) (appearing in $18.1 \%$ of the analysed samples). The three studied species revealed the presence of UV-328, which was the most frequently detected compound. In Boops boops, UV-326 and UV-360 were also found. The maximum concentrations were detected in this omnivorous fish (e.g., $29.8 \mathrm{ng} \mathrm{g}^{-1}$ for UV-328 and $34.9 \mathrm{ng} \mathrm{g}^{-1}$ for UV-326). In viscera, UV-328, UV 
329 , and UV 360 were found in a high number of samples (26.4\%), usually at concentrations lower than $10 \mathrm{ng} \mathrm{g}^{-1}$. However, relatively high concentrations were measured in some samples, such as $45.6 \mathrm{ng} \mathrm{g}^{-1}$ for UV-328 in Boops boops. Although the highest concentrations were recorded in the samples from January 2017, there is not a clear trend of temporal variability. In this case, UV-329 was the most frequently detected (in $8.3 \%$ of the analysed samples), appearing at all the locations and in all species at concentrations ranging from 1.34 to $10.7 \mathrm{ng} \mathrm{g}^{-1}$ at the three studied locations [60]. These values are in the same order of magnitude of the maximum levels found by other authors in marine fish species (up to $55 \mathrm{ng} \mathrm{g}^{-1}$ wet weight (ww)). However, other authors reported values as low as $0.001 \mathrm{ng} \mathrm{g}^{-1}(\mathrm{ww})[16]$.

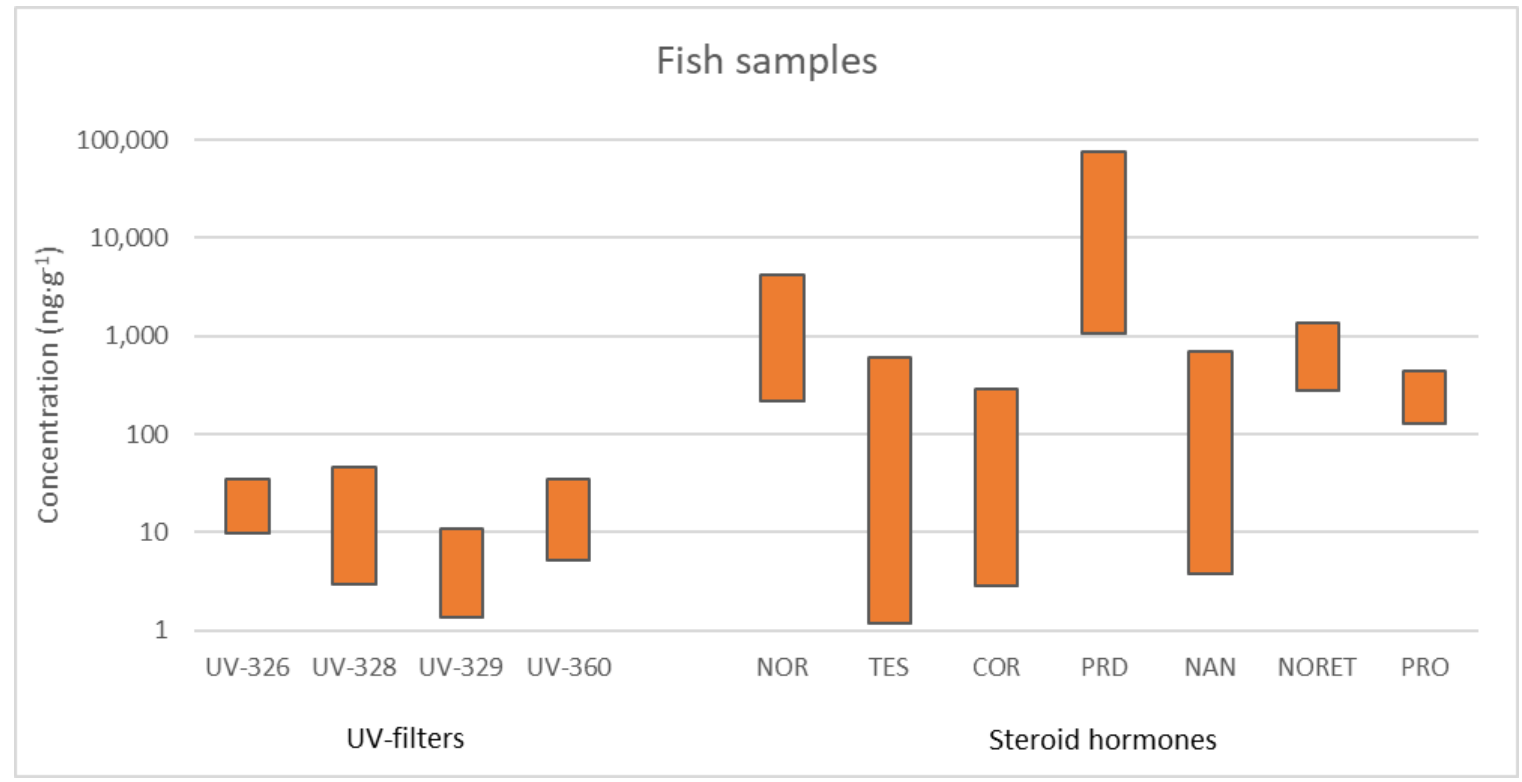

Figure 5. Range of concentrations $\left(\mathrm{ng} \mathrm{g}^{-1}\right.$ ) for detected BUVSs and steroid hormones in fish samples.

Similarly to the observed in sludge and sediments, cytostatic compounds were not detected in fish samples. The reason is probably that their concentrations were too low, and inputs of these target compounds from effluents were diluted in the outfall.

In a first evaluation of the presence of steroid hormones in fish tissue, samples of Boops boops and Sphoeroides marmoratus captured close to the marine outfall of the largest WWTP were analysed to determine whether these species present measurable concentrations of steroid hormones. In this sense, steroid hormones were evaluated in the muscle, viscera, and skin of both species. The behaviour in both species was similar, and muscle samples exhibited the highest number of detected steroid hormones (up to 7 of 15 compounds under study). Nevertheless, their concentrations were in most cases below the quantification limits. In contrast, viscera samples exhibited fewer positive compounds (4 of the 15 studied compounds), but the concentrations were significantly greater than those in muscle samples. Regarding skin samples, they exhibited the lowest positive analysis, and the concentrations were much lower than those observed in viscera. No significant differences were observed between the two fish species despite the differences between them. The concentrations of the eight detected compounds ranged from less than the quantification limits to $3.95 \mathrm{\mu g} \mathrm{g}^{-1}$ [49]. After this first evaluation of hormones in fishes, a 2-year monitoring was conducted in the three marine outfalls under study. As in the preliminary results, the concentrations found in fishes were low, and some hormones, such as diethylstilboestrol, $17 \beta$-oestradiol, or $17 \alpha$-ethinyloestradiol, were not detected in any case in fish tissue. Overall, the fishes captured in the surrounding area of marine outfalls of WWTP2 and WWTP4 exhibited more positive analyses in comparison with the fishes of the outfall of WWTP3. In fact, $52.2 \%$ and $57.1 \%$ of studied fish muscle presented at least one steroid hormone in the samples taken from 
marine outfalls of WWTP2 and WWTP4, while the positive percentage in samples taken from the marine outfall of WWTP3 was 38.1\%. For example, the concentrations of norgestrel ranged from 0.70 to $3.62 \mu \mathrm{g} \mathrm{g}^{-1}$ and from 0.22 to $2.21 \mu \mathrm{g} \mathrm{g}^{-1}$ in WWTP2 and WWTP4, respectively, while in WWTP3, norgestrel was detected only in one sample at a concentration of $1.97 \mu \mathrm{g} \mathrm{g}^{-1}$. Something similar occurred for norethisterone, for which the values ranged from 0.28 to $1.36 \mu \mathrm{g} \mathrm{g}^{-1}$ in WWTP2 and WWTP4, and it was not detected in WWTP3. Regarding the concentrations found in the different species, there were no significant differences among detected compounds and concentrations between Boops boops and Sphoeroides marmoratus, the two small fishes studied. The most detected compounds in these two species were norgestrel (in $21 \%$ of the samples studied) and prednisone (in $16 \%$ of the samples studied), two synthetic steroid hormones. Concerning Sphyraena viridensis, the concentrations detected were not greater than those found in small fishes. This result can indicate that there is not a clear effect of biomagnification of these compounds in the trophic chain. Nevertheless, in the marine outfalls of WWTP2 and WWTP4, the same trend of the concentrations of prednisone was observed in Sphyraena viridensis. In October 2017, the highest concentrations of the whole study (between 37.0 and $61.2 \mu \mathrm{g} \mathrm{g}^{-1}$ ) were observed, and the concentration of this compound decreased in the individuals captured in the following sampling campaigns. In general, the concentrations were low and not consistent over time. The waters of marine outfalls did not present measurable concentrations of steroid hormones, which could explain the low and inconsistent concentrations of steroid hormones in fish muscle. The study of steroid hormones in fish samples is more limited than that in water or environmental solid samples. In fact, most of the studies are focused on the determination of oestrogens. In this regard, oestrogens such as oestrone, oestriol, or $17 \beta$-oestradiol, were detected in fish muscle or plasma at concentrations of $\mathrm{ng} \mathrm{g}^{-1}$ and $\mathrm{pg} \mathrm{mL}^{-1}$, respectively [61,62], while a study performed in commercial fish samples detected $17 \beta$-oestradiol or corticosterone in hairtail muscle samples at $\mathrm{ng} \mathrm{g}^{-1}$ level, as well [63].

\section{Conclusions}

The temporal occurrence of several groups of emerging contaminants (UV filters and stabilizers, cytostatic compounds, and natural and steroid hormones) was revised in different environmental compartments (sewage, sludge, seawater, marine sediments, and fish) in the biodiversity hotspot, highly touristic Canary Islands.

UV stabilizers were quantified in all types of studied samples, with UV-328, UV-329, and UV-360 being the most detected compounds. In relation to cytostatic compounds, they were quantified in several WWTPs, in both influents and effluents, as well as in hospital effluents. Due to the dilution factor of the effluents in the sea, these compounds were not detected in the nearby discharging coastal zones (e.g., seawater sampled in submarine outfalls). They were also not detected in solid matrices (sludge, sediment, and fish).

Steroid hormones were quantified in effluents of WWTPs, but not detected in seawater samples. Nevertheless, in the biota exposed to these marine outfalls, up to eight different steroid hormones, both natural and synthetic, were detected in different tissues. In this regard, more compounds were detected in muscle samples (up to 7 out of 15 studied steroid hormones) but at trace concentrations, while in viscera, concentrations were higher, but fewer compounds were detected.

Given the presence of these pollutants in WWTP effluents, their occurrence in the aquatic ecosystem is proven to come from the discharge of sewages. Although the levels found for these compounds were in the range of $\mathrm{ng} \mathrm{L}^{-1}$, the evidence that they are continually released into the environment has to be considered, specifically taking into account that they could reach fish species that are commonly consumed in the Canary Islands.

Additionally, natural wastewater treatment systems have been revealed to be efficient technologies for the removal of EOCs from urban wastewaters from small communities. Ponds and CWs present remarkable removal capacity, and their combination can provide similar efficiencies to those of conventional WWTPs. 
Supplementary Materials: The following are available online at http://www.mdpi.com/2073-4441/12/9/2548/s1, Table S1: SPE conditions employed for each studied family of compounds, Table S2: MAE conditions employed for each matrix and family of studied EOCs, Table S3: Ionization parameters for the selected families of pollutants, Table S4: Mass spectrometer parameters for the studied compounds, Table S5: Chromatographic conditions for selected families of compounds.

Author Contributions: Conceptualization, M.E.T.-P., S.M.-E., S.S.-V., R.G.-A., J.A.H.-M., Z.S.-F., J.J.S.-R.; Funding acquisition, J.A.H.-M., Z.S.-F., J.J.S.-R.; Sampling, S.M.-E., S.S.-V., R.G.-A., J.A.H.-M.; Methodology, M.E.T.-P., S.M.-E., S.S.-V., R.G.-A., J.A.H.-M., Z.S.-F., J.J.S.-R.; Data analysis, M.E.T.-P., S.M.-E., S.S.-V., R.G.-A., J.A.H.-M., Z.S.-F., J.J.S.-R.; Project administration, J.A.H.-M., Z.S.-F., J.J.S.-R.; Supervision, Z.S.-F., J.J.S.-R.; Writing-original draft, M.E.T.-P., S.M.-E., S.S.-V., R.G.-A.; Writing-review \& editing, M.E.T.-P., S.M.-E., S.S.-V., R.G.-A., J.A.H.-M., Z.S.-F., J.J.S.-R. All authors have read and agreed to the published version of the manuscript.

Funding: This work was supported by funds provided by the Spanish Ministry of Economy and Competitiveness, Research Project CTM2015-66095-C2-1-R and Research Project CEI2018-2-SI1496-6408707. The authors would also like to express their gratitude to the Fundación CajaCanarias y Fundación Bancaria "La Caixa" for their economic support through the Project 2017RECO05.

Acknowledgments: S.M.-E. would like to thank the Universidad de Las Palmas de Gran Canaria for her postdoctoral fellowship. S.S.-V. thanks the University of Las Palmas de Gran Canaria (Spain) for his grant. The authors thank the collaboration of the WWTPs' managers for the support in the WWTP samplings.

Conflicts of Interest: The authors declare no conflict of interest.

\section{Abbreviations}

$\begin{array}{ll}\text { BUVSs } & \text { Benzotriazole ultraviolet stabilizers } \\ \text { CW } & \text { Constructed wetlands } \\ \text { dw } & \text { Dry weight } \\ \text { ECOSAR } & \text { Ecological Structure Activity Relationships Predictive Model } \\ \text { EDCs } & \text { Endocrine-disrupting chemicals } \\ \text { EOCs } & \text { Emerging organic contaminants } \\ \text { EPA } & \text { Environmental Protection Agency } \\ \text { ESI } & \text { Electrospray ionization } \\ \text { FPSE } & \text { Fabric phase sorptive extraction } \\ \text { ISTAC } & \text { Canary Institute of Statistics } \\ \text { LC } & \text { Liquid chromatography } \\ \text { LLE } & \text { Liquid-liquid extraction } \\ \text { LOD } & \text { Limit of detection } \\ \text { MAE } & \text { Microwave-assisted extraction } \\ \text { MeOH } & \text { Methanol } \\ \text { MS } & \text { Mass spectrometry } \\ \text { MS/MS } & \text { Tandem mass spectrometry } \\ \text { PE } & \text { Population equivalent } \\ \text { PLE } & \text { Pressurized liquid extraction } \\ \text { PPCPs } & \text { Pharmaceutical and personal care products } \\ \text { RSD } & \text { Relative standard deviation } \\ \text { SPE } & \text { Solid-phase extraction } \\ \text { UHPLC } & \text { Ultra-high-performance liquid chromatography } \\ \text { UAE } & \text { Ultrasound-assisted extraction } \\ \text { wW } & \text { Wet weight } \\ \text { WWTPs } & \text { Wastewater treatment plants } \\ & \end{array}$

\section{References}

1. Gray, J.S.; Bewers, J.; He, X. Pollution: Approaches to Pollution Control. In Encyclopedia of Ocean Sciences, 3rd ed.; Academic Press: Cambridge, MA, USA, 2019.

2. Beiras, R. Marine Pollution: Sources, Fate and Effects of Pollutants in Coastal Ecosystems; Elsevier: Amsterdam, The Netherlands, 2018.

3. Farré, M.; Pérez, S.; Kantiani, L.; Barceló, D. Fate and toxicity of emerging pollutants, their metabolites and transformation products in the aquatic environment. TrAC Trends Anal. Chem. 2008, 27, 991-1007. [CrossRef] 
4. Bao, L.J.; Wei, Y.L.; Yao, Y.; Ruan, Q.Q.; Zeng, E.Y. Global trends of research on emerging contaminants in the environment and humans: A literature assimilation. Environ. Sci. Pollut. Res. 2014, 22, 1635-1643. [CrossRef]

5. Fent, K.; Chew, G.; Li, J.; Gomez, E. Benzotriazole UV-stabilizers and benzotriazole: Antiandrogenic activity in vitro and activation of aryl hydrocarbon receptor pathway in zebrafish eleuthero-embryos. Sci. Total. Environ. 2014, 482, 125-136. [CrossRef] [PubMed]

6. Liang, X.; Adamovský, O.; Souders, C.L.; Martyniuk, C.J. Biological effects of the benzotriazole ultraviolet stabilizers UV-234 and UV-320 in early-staged zebrafish (Danio rerio). Environ. Pollut. 2019, 245, 272-281. [CrossRef] [PubMed]

7. Zafra-Gómez, A.; Dorival-García, N.; Diaz, J. Marine Pollution: Types, Environmental Significance and Pollution Control; Nova Science Publisher: New York, NY, USA, 2014.

8. Parra-Luna, M.; Martín-Pozo, L.; Hidalgo, F.; Zafra-Gómez, A. Common sea urchin (Paracentrotus lividus) and sea cucumber of the genus Holothuria as bioindicators of pollution in the study of chemical contaminants in aquatic media. A revision. Ecol. Indic. 2020, 113, 106185. [CrossRef]

9. Montes-Grajales, D.; Fennix-Agudelo, M.A.; Miranda-Castro, W. Occurrence of personal care products as emerging chemicals of concern in water resources: A review. Sci. Total. Environ. 2017, 595, 601-614. [CrossRef] [PubMed]

10. Loos, R.; Carvalho, R.; Antonio, D.C.; Comero, S.; Locoro, G.; Tavazzi, S.; Paracchini, B.; Ghiani, M.; Lettieri, T.; Bláha, L.; et al. EU-wide monitoring survey on emerging polar organic contaminants in wastewater treatment plant effluents. Water Res. 2013, 47, 6475-6487. [CrossRef] [PubMed]

11. García-Gil, A.; Schneider, E.A.G.; Mejías, M.; Barceló, D.; Vázquez-Suñé, E.; Díaz-Cruz, S. Occurrence of pharmaceuticals and personal care products in the urban aquifer of Zaragoza (Spain) and its relationship with intensive shallow geothermal energy exploitation. J. Hydrol. 2018, 566, 629-642. [CrossRef]

12. Nödler, K.; Tsakiri, M.; Aloupi, M.; Gatidou, G.; Stasinakis, A.S.; Licha, T. Evaluation of polar organic micropollutants as indicators for wastewater-related coastal water quality impairment. Environ. Pollut. 2016, 211, 282-290. [CrossRef]

13. Zhao, F.; Chen, L.; Yang, L.; Sun, L.; Li, S.; Li, M.; Feng, Q. Effects of land use and rainfall on sequestration of veterinary antibiotics in soils at the hillslope scale. Environ. Pollut. 2020, 260, 114112. [CrossRef]

14. Patel, M.; Kumar, R.; Kishor, K.; Mlsna, T.; Pittman, C.U.; Mohan, D. Pharmaceuticals of emerging concern in aquatic systems: Chemistry, occurrence, effects, and removal methods. Chem. Rev. 2019, 119, 3510-3673. [CrossRef] [PubMed]

15. Mekni, S.; Barhoumi, B.; Aznar-Alemany, Ò.; Touil, S.; Driss, M.R.; Barceló, D.; Eljarrat, E. Occurrence of halogenated flame retardants in sediments and sea urchins (Paracentrotus lividus) from a North African Mediterranean coastal lagoon (Bizerte, Tunisia). Sci. Total. Environ. 2019, 654, 1316-1325. [CrossRef] [PubMed]

16. Kim, J.W.; Ramaswamy, B.R.; Chang, K.H.; Isobe, T.; Tanabe, S. Multiresidue analytical method for the determination of antimicrobials, preservatives, benzotriazole UV stabilizers, flame retardants and plasticizers in fish using ultra high performance liquid chromatography coupled with tandem mass spectrometry. $J$. Chromatogr. A 2011, 1218, 3511-3520. [CrossRef] [PubMed]

17. Kim, J.W.; Chang, K.H.; Isobe, T.; Tanabe, S. Acute toxicity of benzotriazole ultraviolet stabilizers on freshwater crustacean (Daphnia pulex). J. Toxicol. Sci. 2011, 36, 247-251. [CrossRef]

18. Guedes-Alonso, R.; Esponda, S.M.; Herrera-Melián, J.A.; Rodríguez-Rodríguez, R.; Ojeda-González, Z.; Landívar-Andrade, V.; Sosa-Ferrera, Z.; Santana-Rodríguez, J.J. Pharmaceutical and personal care product residues in a macrophyte pond-constructed wetland treating wastewater from a university campus: Presence, removal and ecological risk assessment. Sci. Total. Environ. 2020, 703, 135596. [CrossRef]

19. Crites, R.W.; Middlebrooks, E.J. Natural Wastewater Treatment Systems, 2nd ed.; CRC Press: Boca Raton, FL, USA, 2014.

20. Molinos-Senante, M.; Gómez, T.; Caballero, R.; Hernández-Sancho, F.; Sala-Garrido, R. Assessment of wastewater treatment alternatives for small communities: An analytic network process approach. Sci. Total. Environ. 2015, 532, 676-687. [CrossRef]

21. Gruchlik, Y.; Linge, K.; Joll, C.A. Removal of organic micropollutants in waste stabilisation ponds: A review. J. Environ. Manag. 2018, 206, 202-214. [CrossRef]

22. Mara, D. Domestic Wastewater Treatment in Developing Countries; Routledge: London, UK, 2013. 
23. Reddy, L.; Kumar, D.; Asolekar, S.R. Typologies for successful operation and maintenance of horizontal sub-surface flow constructed wetlands. Sciences 2014, 6, 157-164.

24. Apel, C.; Tang, J.; Ebinghaus, R. Environmental occurrence and distribution of organic UV stabilizers and UV filters in the sediment of Chinese Bohai and Yellow Seas. Environ. Pollut. 2018, 235, 85-94. [CrossRef]

25. Mizukawa, A.; Molins-Delgado, D.; De Azevedo, J.C.R.; Fernandes, C.V.S.; Díaz-Cruz, S.; Barceló, D. Sediments as a sink for UV filters and benzotriazoles: The case study of Upper Igua?u watershed, Curitiba (Brazil). Environ. Sci. Pollut. Res. 2017, 24, 18284-18294. [CrossRef]

26. Tousova, Z.; Oswald, P.; Slobodnik, J.; Bláha, L.; Muz, M.; Hu, M.; Brack, W.; Krauss, M.; Di Paolo, C.; Tarcai, Z.; et al. European demonstration program on the effect-based and chemical identification and monitoring of organic pollutants in European surface waters. Sci. Total. Environ. 2017, 601-602, 1849-1868. [CrossRef] [PubMed]

27. Vimalkumar, K.; Arun, E.; Krishna-Kumar, S.; Poopal, R.K.; Nikhil, N.P.; Subramanian, A.; Ramaswamy, B.R. Occurrence of triclocarban and benzotriazole ultraviolet stabilizers in water, sediment, and fish from Indian rivers. Sci. Total. Environ. 2018, 625, 1351-1360. [CrossRef] [PubMed]

28. Wick, A.; Jacobs, B.; Kunkel, U.; Heininger, P.; Ternes, T.A. Benzotriazole UV stabilizers in sediments, suspended particulate matter and fish of German rivers: New insights into occurrence, time trends and persistency. Environ. Pollut. 2016, 212, 401-412. [CrossRef]

29. Johnson, A.C.; Jürgens, M.D.; Williams, R.; Kümmerer, K.; Kortenkamp, A.; Sumpter, J.P. Do cytotoxic chemotherapy drugs discharged into rivers pose a risk to the environment and human health? An overview and UK case study. J. Hydrol. 2008, 348, 167-175. [CrossRef]

30. Zhang, J.; Chang, V.W.C.; Giannis, A.; Wang, J.-Y. Removal of cytostatic drugs from aquatic environment: A review. Sci. Total. Environ. 2013, 445-446, 281-298. [CrossRef] [PubMed]

31. Kovács, R.; Csenki, Z.; Bakos, K.; Urbányi, B.; Horvath, A.; Garaj-Vrhovac, V.; Gajski, G.; Gerić, M.; Negreira, N.; De Alda, M.L.; et al. Assessment of toxicity and genotoxicity of low doses of 5-fluorouracil in zebrafish (Danio rerio) two-generation study. Water Res. 2015, 77, 201-212. [CrossRef]

32. Brezovšek, P.; Eleršek, T.; Filipič, M. Toxicities of four anti-neoplastic drugs and their binary mixtures tested on the green alga Pseudokirchneriella subcapitata and the cyanobacterium Synechococcus leopoliensis. Water Res. 2014, 52, 168-177. [CrossRef]

33. Trombini, C.; Da Fonseca, T.G.; Morais, M.D.B.; Rocha, T.L.; Blasco, J.; Bebianno, M.J. Toxic effects of cisplatin cytostatic drug in mussel Mytilus galloprovincialis. Mar. Environ. Res. 2016, 119, 12-21. [CrossRef]

34. Borgatta, M.; Decosterd, L.A.; Waridel, P.; Buclin, T.; Chèvre, N. The anticancer drug metabolites endoxifen and 4-hydroxy-tamoxifen induce toxic effects on Daphnia pulex in a two-generation study. Sci. Total. Environ. 2015, 520, 232-240. [CrossRef]

35. Guedes-Alonso, R.; Sosa-Ferrera, Z.; Santana-Rodríguez, J.J. Analytical Methods for the Determination of Steroid Hormones in Environmental Systems; Nova Publishing: New York, NY, USA, 2020.

36. Adeel, M.; Song, X.; Wang, Y.; Francis, D.; Yang, Y. Environmental impact of estrogens on human, animal and plant life: A critical review. Environ. Int. 2017, 99, 107-119. [CrossRef]

37. Leet, J.K.; Gall, H.E.; Sepúlveda, M.S. A review of studies on androgen and estrogen exposure in fish early life stages: Effects on gene and hormonal control of sexual differentiation. J. Appl. Toxicol. 2011, 31, 379-398. [CrossRef] [PubMed]

38. Cano-Nicolau, J.; Garoche, C.; Hinfray, N.; Pellegrini, E.; Boujrad, N.; Pakdel, F.; Kah, O.; Brion, F. Several synthetic progestins disrupt the glial cell specific-brain aromatase expression in developing zebra fish. Toxicol. Appl. Pharmacol. 2016, 305, 12-21. [CrossRef] [PubMed]

39. McNeil, P.L.; Nebot, C.; Cepeda, A.; Sloman, K.A. Environmental concentrations of prednisolone alter visually mediated responses during early life stages of zebrafish (Danio rerio). Environ. Pollut. 2016, 218, 981-987. [CrossRef] [PubMed]

40. Rivero-Wendt, C.L.G.; De Oliveira, R.; Monteiro, M.S.; Domingues, I.; Soares, A.M.V.M.; Grisolia, C.K. Steroid androgen $17 \alpha$-methyltestosterone induces malformations and biochemical alterations in zebrafish embryos. Environ. Toxicol. Pharmacol. 2016, 44, 107-113. [CrossRef] [PubMed]

41. Nasiri, M.; Ahmadzadeh, H.; Amiri, A. Sample preparation and extraction methods for pesticides in aquatic environments: A review. TrAC Trends Anal. Chem. 2020, 123, 115772. [CrossRef] 
42. Esponda, S.M.; Sosa-Ferrera, Z.; Santana-Rodríguez, J.J. On-line solid-phase extraction coupled to ultra-performance liquid chromatography with tandem mass spectrometry detection for the determination of benzotriazole UV stabilizers in coastal marine and wastewater samples. Anal. Bioanal. Chem. 2012, 403, 867-876. [CrossRef] [PubMed]

43. Santana-Viera, S.; Hernández-Arencibia, P.; Sosa-Ferrera, Z.; Santana-Rodríguez, J.J. Simultaneous and systematic analysis of cytostatic drugs in wastewater samples by ultra-high performance liquid chromatography tandem mass spectrometry. J. Chromatogr. B Anal. Technol. Biomed. Life Sci. 2019, 1110-1111, 124-132. [CrossRef]

44. Guedes-Alonso, R.; Sosa-Ferrera, Z.; Santana-Rodríguez, J.J. An on-line solid phase extraction method coupled with UHPLC-MS/MS for the determination of steroid hormone compounds in treated water samples from waste water treatment plants. Anal. Methods 2015, 7, 5996-6005. [CrossRef]

45. Esponda, S.M.; Sosa-Ferrera, Z.; Santana-Rodríguez, J.J. Microwave-assisted extraction combined with on-line solid phase extraction followed by ultra-high-performance liquid chromatography with tandem mass spectrometric determination of benzotriazole UV stabilizers in marine sediments and sewage sludges. J. Sep. Sci. 2013, 36, 781-788. [CrossRef]

46. Santana-Viera, S.; Tuček, J.; Torres-Padrón, M.E.; Sosa-Ferrera, Z.; Santana-Rodríguez, J.J.; Halko, R. Cytostatic compounds in sludge and sediment: Extraction and determination by a combination of microwave-assisted extraction and UHPLC-MS/MS. Anal. Bioanal. Chem. 2020, 412, 3639-3651. [CrossRef]

47. Guedes-Alonso, R.; Santana-Viera, S.; Esponda, S.M.; Afonso-Olivares, C.; Sosa-Ferrera, Z.; Santana-Rodríguez, J.J. Application of microwave-assisted extraction and ultra-high performance liquid chromatography-tandem mass spectrometry for the analysis of sex hormones and corticosteroids in sewage sludge samples. Anal. Bioanal. Chem. 2016, 408, 6833-6844. [CrossRef] [PubMed]

48. Santana-Viera, S.; Marzullo, L.; Padrón, M.E.T.; Del Bubba, M.; Sosa-Ferrera, Z.; Santana-Rodríguez, J.J. Microwave assisted extraction for the determination of antineoplastic compounds in marine fish. J. Food Compos. Anal. 2019, 82, 103241. [CrossRef]

49. Guedes-Alonso, R.; Sosa-Ferrera, Z.; Santana-Rodríguez, J.J. Determination of steroid hormones in fish tissues by microwave-assisted extraction coupled to ultra-high performance liquid chromatography tandem mass spectrometry. Food Chem. 2017, 237, 1012-1020. [CrossRef] [PubMed]

50. Montesdeoca-Esponda, S.; Álvarez-Raya, C.; Torres, M.; Sosa-Ferrera, Z.; Santana-Rodríguez, J.J. Monitoring and environmental risk assessment of benzotriazole UV stabilizers in the sewage and coastal environment of Gran Canaria (Canary Islands, Spain). J. Environ. Manag. 2019, 233, 567-575. [CrossRef]

51. Carpinteiro, I.; Ramil, M.; Rodriguez, I.; Nogueira, J.M.F. Combining stir-bar sorptive extraction and large volume injection-gas chromatography-mass spectrometry for the determination of benzotriazole UV stabilizers in wastewater matrices. J. Sep. Sci. 2012, 35, 459-467. [CrossRef]

52. Liu, Y.-S.; Ying, G.-G.; Shareef, A.; Kookana, R.S. Simultaneous determination of benzotriazoles and ultraviolet filters in ground water, effluent and biosolid samples using gas chromatography-tandem mass spectrometry. J. Chromatogr. A 2011, 1218, 5328-5335. [CrossRef]

53. Negreira, N.; De Alda, M.L.; Barceló, D. Degradation of the cytostatic etoposide in chlorinated water by liquid chromatography coupled to quadrupole-Orbitrap mass spectrometry: Identification and quantification of by-products in real water samples. Sci. Total. Environ. 2015, 506, 36-45. [CrossRef]

54. Yin, J.; Shao, B.; Zhang, J.; Li, K. A preliminary study on the occurrence of cytostatic drugs in hospital effluents in Beijing, China. Bull. Environ. Contam. Toxicol. 2010, 84, 39-45. [CrossRef]

55. Gómez-Canela, C.; Cortes-Francisco, N.; Oliva, X.; Pujol, C.; Ventura, F.; Lacorte, S.; Caixach, J. Occurrence of cyclophosphamide and epirubicin in wastewaters by direct injection analysis-liquid chromatography-high-resolution mass spectrometry. Environ. Sci. Pollut. Res. 2012, 19, 3210-3218. [CrossRef]

56. Castiglioni, S.; Bagnati, R.; Calamari, D.; Fanelli, R.; Zuccato, E. A multiresidue analytical method using solid-phase extraction and high-pressure liquid chromatography tandem mass spectrometry to measure pharmaceuticals of different therapeutic classes in urban wastewaters. J. Chromatogr. A 2005, 1092, 206-215. [CrossRef]

57. Steger-Hartmann, T.; Kümmerer, K.; Schecker, J. Trace analysis of the antineoplastics ifosfamide and cyclophosphamide in sewage water by twostep solid-phase extraction and gas chromatography-mass spectrometry. J. Chromatogr. A 1996, 726, 179-184. [CrossRef] 
58. Damkjaer, K.; Weisser, J.J.; Msigala, S.C.; Mdegela, R.; Styrishave, B. Occurrence, removal and risk assessment of steroid hormones in two wastewater stabilization pond systems in Morogoro, Tanzania. Chemosphere 2018, 212, 1142-1154. [CrossRef] [PubMed]

59. Chen, J.; Liu, Y.S.; Deng, W.J.; Ying, G.G. Removal of steroid hormones and biocides from rural wastewater by an integrated constructed wetland. Sci. Total. Environ. 2019, 660, 358-365. [CrossRef] [PubMed]

60. Montesdeoca-Esponda, S.; Torres-Padrón, M.E.; Novák, M.; Krchová, L.; Sosa-Ferrera, Z.; Santana-Rodríguez, J.J. Occurrence of benzotriazole UV stabilizers in coastal fishes. J. Environ. Manag. 2020, 269, 110805. [CrossRef]

61. Bussy, U.; Chung-Davidson, Y.W.; Buchinger, T.J.; Li, K.; Li, W. High-sensitivity determination of estrogens in fish plasma using chemical derivatization upstream UHPLC-MSMS. Steroids 2017, 123, 13-19. [CrossRef]

62. Jakimska, A.; Huerta, B.; Bargańska, Ż.; Kot-Wasik, A.; Rodriguez-Mozaz, S.; Barceló, D. Development of a liquid chromatography-tandem mass spectrometry procedure for determination of endocrine disrupting compounds in fish from Mediterranean rivers. J. Chromatogr. A 2013, 1306, 44-58. [CrossRef]

63. Wang, H.; Zhou, X.; Zhang, Y.; Chen, H.; Li, G.; Xu, Y.; Zhao, Q.; Song, W.; Jin, H.; Ding, L. Dynamic microwave-assisted extraction coupled with salting-out liquid-liquid extraction for determination of steroid hormones in fish tissues. J. Agric. Food Chem. 2012, 60, 10343-10351. [CrossRef]

(C) 2020 by the authors. Licensee MDPI, Basel, Switzerland. This article is an open access article distributed under the terms and conditions of the Creative Commons Attribution (CC BY) license (http://creativecommons.org/licenses/by/4.0/). 